\title{
Rize İli Seyahat Acentalarının Sosyal Medya Pazarlamasına Yönelik Algı ve Tutumları
}

\author{
Elif ACUNER*
}

Kübra KÜÇÜK ${ }^{\dagger}$

\begin{abstract}
$\ddot{O} \mathbf{z}$
Bu çalışmanın amacı Rize'de faaliyet gösteren seyahat acentaların sosyal medya pazarlamasına yönelik algı ve tutumlarını belirlemektir. Çalışmanın teorik alt yapısı sosyal ağlar teorisine dayandırılmaktadır. Çalışmanın evrenini TÜRSAB'a kayıtlı olup, Rize ilinde faaliyet gösteren seyahat acentaları oluşturmaktadır. Çalışmada betimsel araştırma modellerinden tarama araştırmasının kesitsel tarama türü kullanılmışır. Buna ek olarak işletmelerin sosyal medya pazarlamasına yönelik tutumlarını desteklemek için nitel araştırma yöntemlerinden biri olan tarama araştırması kullanılmıștır. İșletmelerin Instagram hesapları içerik analizi ile incelenmiştir. Yapılan çalışma sonucunda seyahat acentalarının sosyal medya pazarlamasına yönelik algı ve tutumlarının olumlu olduğu görülmüştür. Diğer yandan işletmelerin sosyal medyayı; şirketlerini ve ürünlerini tanıtmak, marka farkındalığı oluşturmak ve satış geliştirmek amaçlı kullandıklarına yönelik sonuçlara ulaşıııışıı. Sosyal medya pazarlamasının işletmeler tarafindan daha etkin ve verimli şekilde kullanılması için işletme bünyesinde sosyal medya pazarlaması ile ilgilenecek donanımlı personelin bulundurulması ve gerekli eğitimlerin alınması önem taşımaktadır.
\end{abstract}

Anahtar Kelimeler: Sosyal Medya Pazarlaması, İşletme Algı ve Tutumları, Seyahat Acentaları, Rize.

\section{Perceptions and Attitudes of Rize Travel Agencies Towards Social Media Marketing}

Abstract

The aim of this study is to determine the perception and attitudes of travel agencies operating in Rize towards social media marketing. The theoretical background of the study is based on the theory of social networks. The universe of the study consists of travel agencies operating in Rize, which are registered in TÜRSAB. The cross-sectional screening type of screening research from descriptive research models was used in the study. In addition, screening research, one of the qualitative research methods, has been used to support businesses ' attitudes towards social media marketing. The Instagram accounts of businesses have been analyzed with content analysis. The study concluded that the perception and attitude of travel agencies towards social media marketing is positive and that businesses use social media to promote companies and products, create brand awareness, and develop sales. In order to use social media marketing more effectively and efficiently by businesses, it is necessary to have well-equipped personnel to deal with social media marketing and to receive training on social media marketing.

Keywords: Social Media Marketing, Business Perception and Attitudes, Travel Agencies, Rize.

Geliş/Received: 14.10 .2020

Kabul/Accepted: 22.06 .2021

* Bu çalışma için, Recep Tayyip Erdoğan Üniversitesi Sosyal ve Beşerî Bilimler Etik Kurulu'ndan 20.10.2020 tarih ve 2020/125 sayılı karar ile etik kurul izni alınmıştır.

\footnotetext{
* Dr. Öğr. Üyesi, Recep Tayyip Erdoğan Üniversitesi Ardeşen Turizm Fakültesi Turizm İşletmeciliği Bölümü Öğretim Üyesi, elif.acuner@erdogan.edu.tr, ORCID: 0000-0002-7769-8705.

† Yüksek Lisans Öğrencisi, Recep Tayyip Erdoğan Üniversitesi Sosyal Bilimler Enstitüsü Turizm İşletmeciliği Anabilim Dalı, kubra kucuk191@erdogan.edu.tr, ORCID: 0000-0002-7876-4698.

(Makale Türü: Araştırma Makalesi)
} 


\section{Giriş}

Sosyal medya, kişilerin sosyalleşmesine olanak sağlayan (Kılıç, Kırlı ve Esen, 2017), bireylerin fotoğraf ya da video gibi paylaşımlar yapabildiği (Karabulut ve Bulut, 2017), yapılan paylaşımlarla farklı insanları olumlu ya da olumsuz etkileyebilen çok yönlü bir alan olarak tanımlanmaktadır (Eryılmaz ve Şengül, 2016). İşletmeler, sosyal medya sayesinde daha fazla kişi ile etkileşim ve iletişim kurabildiklerinden, ürünlerini pazarlamak için sosyal medya platformlarını aracı olarak kullanmaktadır (Castronovo ve Huang, 2012). Bu eylemlerden doğan faaliyet sosyal medya pazarlaması faaliyetidir. Sosyal medya pazarlaması, işletmelerin ürünlerini ya da hizmetlerini sosyal ağlar vasıtasıyla daha geniş topluluklara ulaştırma süreci olarak tanımlanmaktadır (Weinberg, 2009).

Sosyal medya pazarlaması, diğer sektörlerde olduğu gibi turizm sektöründe de gün geçtikçe yaygın olarak kullanılmaktadır (Eröz ve Doğdubay, 2012). Tüketiciler ise sosyal medya platformlarında seyahat öncesinde planladıkları tatilleri ile ilgili bilgi toplamakta ve diğer ürünlerle kıyaslama yapmaktadırlar. Ayrıca, hizmet ya da ürün ile ilgili bilgi topladıktan sonra satın alma davranışını gerçekleştirmektedirler (Xiang ve Gretzel, 2010; Huang, Basu, ve Hsu, 2010; Burgess, Sellitto, Cox, ve Buultjens, 2011; İşlek, 2012; K1lıç, vd., 2017; Yıldız Sanay, 2017; Şahin, Çağlıyan, ve Başer, 2017). Tüketiciler seyahat sırasında ve sonrasında ürün ya da hizmet ile ilgili yaşamış oldukları deneyimlerine ilişsin olumlu ya da olumsuz değerlendirmelerini sosyal medya platformlarını kullanarak yapmaktadırlar (Civelek ve Dalgın, 2013). Tüketicilerin ürün ya da hizmet ile ilgili yapmış oldukları olumlu ya da olumsuz değerlendirmeler, işletmeler tarafindan sosyal medya aracılığı ile kolaylıkla takip edilebilir ve yapılan değerlendirmeler sonrasında işletmelerin kendilerini yenilemeleri ve geliştirebilmeleri açısından çeşitli avantajlara sahip olacakları söylenebilir.

Buna göre işletmelerin sağlayacağı avantajlar ya da faydalar arasında; marka farkındalığının oluşturulması (Yung, 1997; Park ve Oh 2012; Yılmazdoğan ve Özel, 2014; Aspasia ve Ourania, 2014; Seo ve Park, 2018), ürünlerin küresel ölçekte pazarlama imkânına sahip olmas1 (Pan, MacLaurin, ve Crotts, 2007; Inversini, Cantoni, ve Buhalis, 2009; Leung, Law, ve Lee, 2011), reklam giderlerinin azaltılması (Eröz ve Doğdubay, 2012), satışların arttırılması (Jones, Borgman, ve Ulusoy, 2015) tüketicilerle yakından etkileşim ve iletişim kurulması (Buzlukçu, 2015; Gümüş ve Kütahyali, 2017; Torun, 2017; Tekeli, 2018), rakip firmalara karşı rekabet üstünlüğü sağlanması (Baş, 2015; Karabulut ve Bulut, 2015) yer almaktadır. Her ne kadar günümüzde sosyal medya pazarlamasının işletmeler tarafından kullanımı yaygın olsa da bazı işletmeler tarafından sosyal medya pazarlama faaliyetleri ihmal edilmektedir (Hays, Page, ve Buhalis, 2013). İşletmeler tarafından sosyal medya pazarlama 
faaliyetinin tercih edilmemesinin çeşitli nedenleri bulunmaktadır. $\mathrm{Bu}$ nedenler arasında; işletmelerin sosyal medya pazarlaması için profesyonel personellerinin olmaması (Kaşl1, 2006; Gümüş ve Kütahyali, 2017; Karabulut ve Bulut, 2017; Tekeli, 2018) ve sosyal medya pazarlamasıyla ilgili yeterli bilgilerinin ve zamanlarının olmaması (Jones, vd., 2015) gibi nedenler sıralanmaktadır.

“Türkiye Turizm Stratejisi 2023”te "Yayla Koridoru” içerisinde yer alan Rize ilinin sahip olduğu turizm potansiyelinin turistlere tanıtılmasında önemli aktörlerden bir tanesi de seyahat acentalarıdır. Rize'nin turizm potansiyeli ile ilgili gerçekleştirilen pazarlama çalışmalarında ve özellikle tutundurma faaliyetlerinde sosyal medya platformları sıklıkla tercih edilmektedir. $\mathrm{Bu}$ çalışmanın amaçlarında bir tanesi Rize ilinde bulunan seyahat acentası çalışanlarının sosyal medya pazarlamasına yönelik algı ve tutumlarını belirlemektir. Diğer taraftan çalışma ile başka bir husus daha amaçlanmıştır. Yayla turizmi ile ön plana çıkmış olan Rize ilinde bulunan konaklama işletmelerinin, sosyal medya kullanım durumları ve sosyal medya hesapları içerik açısından analiz edilmiştir (bkz: Yıldırım ve Erkılıç, 2019). Ancak literatürde Rize ilinde bulunan seyahat acentalarının sosyal medya hesaplarının incelendiği bir çalışmaya rastlanmamıştır. Buradan yola çıkılarak Rize ili seyahat acentalarının "Instagram Hesaplarının" içerik analizi ile incelenerek sosyal medya pazarlamasını etkin şekilde kullanıp kullanmadıkları tespit edilecektir. Araştırma sonuçlarına bağlı olarak sektör temsilcilerine yönelik, Rize ilinin sahip olduğu turistik ürünlerin pazarlanmasında sosyal medya pazarlama araçlarının etkin kullanılması için çeşitli önerilerin geliştirilmesi hedeflenmiştir. Çalışmanın sonuçları ve çalışma ile getirilecek önerilerden dolayı, diğer taraftan Rize ilinde faaliyette bulunan seyahat acentası çalışanlarının sosyal medya pazarlamasına yönelik algı ve tutumlarının belirlenmesi ve acentalar için sosyal medya kullanım etkinliğinin tespit edilmesi ayrıca literatüre sağladığı katkılardan dolayı çalışma önem taşımaktadır. Ayrıca belirlenen örneklem üzerinden elde edilen sonuçlar ile ilgili işletmelerin kendileri için çıkarım yapma şansına sahip olmaları da, çalışmanın bir diğer önemli çıktısı olarak kabul edilebilir.

\section{Literatür Taraması}

Sosyal ağ teorisi, sosyal ağlar üzerinde birbirleriyle bağlantıda olan kişiler arasındaki ilişkiyi açıklamak için kullanılmaktadır (Hartline, Mirrokni, \& Sundararajan, 2008). Sosyal ağ teorisine dayandırılarak açıklanan bu ilişkide, çeşitli sosyal medya araçlarının aktif şekilde kullanılması işletmelere birçok avantaj sağlamaktadır. Bu bağlamda sosyal medya, tüketici ve işletmeler arasındaki ilişkide köprü vazifesi üstlenmektedir.

Tüketiciler sosyal medya platformlarını genel olarak diğer kişilerle bağlantı kurmak, eğlenmek ve bilgi edinmek için kullanmaktadırlar. Diğer taraftan tüketiciler, üreticileri daha 
doğru bir ifade ile hizmet ifa eden (turizm) işletmelerini de takibe almaktadırlar. Tüketicilerin sosyal medya platformlarından işletmeleri takip etme nedenleri arasında ise; sunulan hizmet ile işletme hakkında bilgi sağlamak, indirim ve promosyonları takip etmek ve diğer tüketicilerin değerlendirmelerini incelemek gibi amaçlar yer almaktadır (Yanar ve Y1lmaz, 2017; Özeltürkay, Bozyiğit ve Gülmez 2017, Demirci Orel ve Arık, 2019;). İşletmeler ise sosyal medya araçları sayesinde küresel ölçekte ürünlerini pazarlama firsatı yakalayabilmekte, marka bilinirliği ve imajın geliştirilmesi için avantajlar sağlayabilmektedir (Karaahmet ve Aydın, 2017). İşletmeler tüketicilere; reklam, satış, promosyon, duyuru gibi faaliyetlerini sosyal ağlar üzerinden iletmektedir. İletiler sayesinde satışların artmasına bağlı olarak işletme gelirlerinin yükselmesine, küresel ölçekte ürün ve firma tanıtımına, marka değerinin yükselmesine, müşteri portföyünün gelişmesine katkı sağlanmaktadır (Hartline, Mirrokni, ve Sundararajan, 2008; Çiftçi, 2016). Bilindiği üzere işletmelerde, sosyal medya pazarlamasında blog ve mikrobloglardan ziyade, sosyal ağlar tercih edilmektedir (Yılmazdoğan ve Özel, 2014). Diğer sektörlerde olduğu gibi turizm sektöründe de işletmeler, "Instagram", "Facebook", "Youtube", "Twitter" ve "Foursque" gibi sosyal medya platformalarını kullanarak sosyal medya pazarlamasını rahat bir şekilde gerçekleştirmektedir (Buzlukçu, 2015; Çiftçi, 2016; Karabulut ve Bulut, 2017; Tekeli, 2018).

İşletmeler tarafindan sosyal medya platformlarında düzenli olarak paylaşım yapılması, tüketicilerin algıları üzerinde olumlu imaj yaratılmasına katkı sağlamaktadır. Çünkü sürekli ve tutarlı paylaşım yapmayan işletmeler tüketiciler tarafından güvenilir bulunmamaktadır (Çetin ve Taşdemir, 2018). Halbuki işletmelerin; reklamlarla tüketiciye karşı avantajlı kampanyalar ayrıca ürünlerle ilgili güvenilir içerikler sunması, farklı sosyal medya platformlarında yer alması ve reklamların bilgilendirme derecesinin yüksek olması, müşterilerle işletme arasında empati yapabilme imkanı sağlamaktadır. Bu tür sürekli ve tutarlı paylaşımlar sayesinde müşteri sadakati artacak ve tüketicilerin işletme ürünlerini satın alma davranışı da pozitif yönde etkilenecektir (Erdoğmuş ve Cicek, 2012; Can ve Serhateri, 2016; Leblebeci Koçer ve Arslan Koçkaya, 2016; Demirci Orel ve Arık, 2019).

Ulusal ve uluslararası literatürde sosyal medya ve turizm sektörü bağlamında çeşitli çalışmalar bulunmaktadır. Bu çalışmaların bazıları turistlerin sosyal medya pazarlamasına yönelik algı ve tutumu, buna bağlı olarak da davranışlarındaki değişim ile ilgili iken; bazıları ise turizm işletmelerin sosyal medya pazarlamasına yönelik görüşlerini tespit etmek üzerinedir.

Y1lmazdoğan (2013), Antalya'da faaliyet gösteren dört ve beş y1ldızlı otel ile tatil köylerinde çalışan yöneticilerin sosyal medya pazarlamasına yönelik algılarını belirlemek için yapmış olduğu çalışmasında; yöneticilerin demografik özellikleri ile sosyal medya 
pazarlamasına yönelik algıları arasında anlamlı bir farklılık olduğu sonucuna ulaşmıştır. Daha ileri bir yaşa sahip olan yöneticiler, genç yöneticilere göre sosyal medya pazarlamasına olumsuz bir yaklaşım sergilemektedirler. Yılmazdoğan çalışmasında, yöneticilerin eğitim seviyesi ve işletmelerin sosyal medya kullanım süresi ile sosyal medya pazarlamasına yönelik algı arasında anlamlı farkl11ıklar bulunduğunu ifade etmiştir.

Buzlukçu (2015), Ege Bölgesi'nde faaliyet gösteren butik ve küçük otel işletmelerinde çalışan yöneticilerin sosyal medya pazarlamasına yönelik algılarını ölçmek için yapmış olduğu çalışmasında; sosyal medya pazarlamasına yönelik eğitim alan yönetici sayısının az olduğu sonucuna ulaşmıştır. Yöneticilerin pazarlama faaliyetlerini Facebook, Instagram, Foursque gibi sosyal medya platformları aracılı̆̆ıyla yaptıklarını belirtmiştir. Buzlukçu (2015) çalışmasında; yöneticilerin, sosyal medya pazarlamasını otel ile ilgili farkındalık oluşturmak, farklı müşterilerle iletişime geçmek ve marka tutundurması amacıyla kullandıklarını belirtmiştir. Yöneticilerin yaşları, eğitim seviyeleri, işletmedeki görevleri, çalışma süreleri ile sosyal medya pazarlamasına yönelik algıları arasında anlamlı bir farklılık bulunduğu çalışmanın diğer sonuçlarından biridir. Ayrıca erkek yöneticilerin kadın yöneticilere göre sosyal medya pazarlamasının işletmelere sağladığı kârlılık konusunda daha olumlu bir algıya sahip olduğu sonucuna ulaşmıştır.

Tekeli (2018), Fethiye ilçesinde bulunan konaklama işletmelerinde çalışan yöneticilerin, sosyal medya pazarlamasının yararlarına yönelik algılarının tespiti için yapmış olduğu çalışmada; yöneticilerin, pazarlama faaliyetinde sadece sosyal medya araçlarının yeterli olmadığını buna ek olarak geleneksel pazarlama yöntemlerinin de kullanılması gerektiği yönündeki görüşlerini ortaya koymuştur.

Baş (2015), İstanbul'da faaliyet gösteren beş yıldızlı konaklama işletmelerinin kullanımının genel bir değerlendirilmesini yapmış olduğu çalışmasında; yöneticilerin sosyal medya kullanımı ile demografik özellikleri arasında anlamlı bir farklılık bulunmadı̆̆ı, buna karşın yöneticilerin sektörde çalışmış olduğu süre ile sosyal medya kullanımı arasında anlamlı bir fark bulunduğunu ortaya koymuştur. Çalışmayla, yöneticilerin sosyal medya platformlarını; rekabet üstünlüğü sağlamak, hizmet kalitesini iyileştirmek ve tüketicilerin isteklerini karşılamak amacıyla kullandıkları belirtilmiştir.

Park ve Oh (2012), Kore'de faaliyet gösteren KAL seyahat acentasının sosyal medya pazarlamasının kullanımına ilişkin yapmış olduğu çalışmasında; işletmenin sosyal medya pazarlaması sayesinde önemli derecede kâr elde ettiği sonucuna ulaşmışlardır. Ayrıca işletmelerin çeşitli taleplere cevap verebilmek için farklı sosyal medya platformları kullandığını 
belirtmişlerdir. Sosyal medya sayesinde tüketicilerle doğrudan iletişim kurma imkânının olduğunu ve marka bilinirliliğinin arttığını da ifade etmişlerdir.

Russel (2010), sosyal medya pazarlamasının konaklama işletmelerinde oluşturduğu etkiyi incelediği çalışmasında; sosyal medya pazarlamasının konaklama işletmeleri için düşük maliyetli bir pazarlama yöntemi olduğu sonucuna ulaşmıştır. İşletmeler sosyal medya pazarlamasını etkin ve verimli kullanması durumunda sosyal medya pazarlamasının işletmelere çok fazla fayda sağlayacağını belirtmiştir.

Aspasia ve Ourania (2014); Yunan gıda üretim işletmelerinin sosyal medya kullanımı ve işletme yöneticilerinin sosyal medya pazarlamasına yönelik algılarını ölçmek için yapmış olduğu çalışmalarında; işletmelerin ürünlerini pazarlamak amacıyla sosyal medya araçlarını kullanmaya yönelik önemli bir çaba gösterdikleri sonucuna ulaşmışlardır. Sosyal medya pazarlamasının işletmelere sağladığı faydaların; marka imajı oluşturmak, tüketiciye ürün, yarışma, ödüller hakkında bilgi sunmak olduğunu belirtmişlerdir.

\section{Araştırmanın Yöntemi}

Kültür ve Turizm Bakanlı̆̆g'nın 2023 Türkiye Turizm Stratejisi'nde belirlenen yayla koridorunda yer alan Rize ilinin sahip olduğu potansiyelin gelişmesi adına, turizm işletmeleri ve özellikle seyahat acentaları tarafindan yürütülen pazarlama faaliyetlerinde, sosyal medya önemli bir rol üstlenmektedir. Buradan yola çıkarak Rize ilinde yer alan seyahat acentalarının sosyal medya pazarlamasına yönelik algı ve tutumlarını tespit etmek önem arz etmektedir. Bu amaç kapsamında ana araştırma sorusu, "Doğu Karadeniz bölgesinde yer alan Rize'de faaliyet gösteren seyahat acentası personelinin sosyal medya pazarlamasina yönelik tutum ve algılar nasıldır?" olarak belirlenmiştir. Ana araştırma sorusuna ek olarak alt sorular şu şekilde belirlenmiştir:

1: Seyahat acentalarında çalışan personellerinin demografik özellikleri ile sosyal medya pazarlamasına ilişkin tutumları arasında anlamlı bir farklılık var mıdır?

2: İşletme çalışanlarının sosyal medya eğitimi alma durumu ile sosyal medya kullanımı arasında anlamlı bir farklılık var midır?

3: İşletmenin sosyal medya araçlarında pazarlama odaklı harcadıkları süre ile sosyal medya pazarlamasına ilişkin tutumları arasında anlamlı bir farklılık var mıdır?

4: İşletmenin sosyal medya kullanım süresi ile sosyal medya pazarlamasına ilişkin tutumları arasında anlamlı bir farklılık var mıdır?

5: Seyahat acentalarında çalışan personellerin işyerinde ki görevi ile sosyal medya pazarlamasına ilişkin tutumları arasında anlamlı bir farklılık var mıdır? 
Araştırma evrenini Rize ilinde faaliyet gösteren seyahat acentaları oluşturmaktadır. Rize Kültür ve Turizm Müdürlügü̈'ne bağlı toplam 45 seyahat acentası faaliyet göstermektedir (Rize Kültür ve Turizm Müdürlüğü, 2020). Çalışmada kullanılan anket “Google Formlar"dan online olarak hazırlanmıştır. Hazırlanan anket katılımcılara, acentalarının web sitesinde bulunan elektronik posta adresinden, işletmenin kullandığ 1 sosyal medya platformlarından olan "Instagram" adresinden ve işletmeye ait "Whatsapp" iletişim kanalından online anket şeklinde ulaştırılmıştır. İşletmelere gönderilen online anket formu sonrasında seyahat acentalarına telefon ile ulaşılıp anketin taraflarına ulaşıp ulaşmadığı kontrol edilmiştir. Rize ilinde kayıtlı olan 7 seyahat acentasına hiçbir şekilde ulaşılamamış olup, 8 acentanın ise katılım sağladığı anket çalışmasında verilerin güvenilir olmamasından dolayı değerlendirmeden çıkarılmıştır. Sonuç olarak 30 acentanın verileri analize dâhil edilmiştir

Çalışmada betimsel araştırma modellerinden tarama araştırmasının kesitsel tarama türü kullanılmıştır. Araştırma da veriler anket yöntemi ile elde edilmiştir. Çalışmanın ölçeği, seyahat acentalarının sosyal medya pazarlamasına yönelik tutum ve algılarını belirlemek amacıyla oluşturulmuş; Yung (1997), Buhalis ve Licata (2002), Özturan ve Roney (2004), Vrana ve Zafiropoulos (2006), Karabulut (2015) çalışmalarında kullanılan ölçeklerin derlenmesi suretiyle hazırlanmıştır. Anket formu üç bölümden oluşmaktadır. Anketin ilk bölümünde seyahat acentası personellerine ait demografik bilgiler ve işletmeye ait bilgiler yer almaktadır. Anketin ikinci bölümünde işletmenin sosyal medya araçlarının pazarlama unsuru olarak kullanım durumlarına yönelik sorular yer almaktadır. Son bölümde ise seyahat acentalarının sosyal medya pazarlamasına yönelik tutum ve algılarını belirlemek için 27 ifade yer almaktadır. 27 yargı cümlesine katılım düzeyini belirlemek için ölçekte 5'li Likert derecelemesi kullanılmıştır. 5'li likert derecelendirmeleri şu şekilde belirtilmiştir; (1): Kesinlikle Katılmıyorum, (2): Katılmıorum, (3): Orta Düzeyde Katılıyorum, (4): Katılıyorum, (5): Kesinlikle Katılıyorum.

Kesitsel araştırma yöntemine ek olarak acentaların sosyal medya pazarlamasına yönelik tutumlarıyla ilgili fikir vermesi açısından nitel araştırma yöntemlerinden olan tarama yöntemi kullanılmıştır. Anket çalışmasına katılan 30 tane seyahat acentasının sosyal medya pazarlaması için en çok kullandığı platformlarından biri olan "Instagram" hesapları içerik analizi ile incelenmiştir. İşletmelerin yapmış oldukları paylaşımlar incelenerek içeriklerle ilişkili temalar oluşturulmuştur. İçerik analizi kapsamında oluşturulan sınıflandırma da; işletme kimliği kapsamında, marka logosu ve sloganın yer alıp almadığı incelenmiştir. Marka farkındalığı kapsamında, "hashtag (\#)”ve “mention (@)” kullanımı, işletmenin sahip olduğu diğer sosyal ağlarla bağlantısı gibi değişkenler incelenmiştir. Etkileşim kapsamında, tüketicilerin yapmış oldukları yorumlar, yapılan yorumların özellikleri ve işletmenin yorumlara cevap verme durumu 


\section{Elif ACUNER, Kübra KÜÇÜK}

Rize İli Seyahat Acentalarının Sosyal Medya Pazarlamasına Yönelik Algı ve Tutumları

incelenmiştir. İçerik kapsamında, işletmenin sahip olduğu takipçi sayısı, gönderi sayısı, beğeni sayısı ve toplam yorum sayısı incelenmiştir. Satış özendirme kapsamında ise ürün promosyon durumu ve gönderilerde internet sitesi linkinin paylaşılıp paylaşılmadığı incelenmiştir.

Anket verilerinin normallik testi sonucunda Kolmogorov-Smirnov'a göre " $p$ " değeri 0,2 ve Shapiro-Wilk'e göre ise " $p$ " değeri 0,059 sonucuna ulaşılmıştır. Buna ek olarak basıklık değeri -0,466 iken çarpıklık değeri ise 3,089'tür. Elde edilen sonuçlara göre veriler normal dağılım göstermektedir ve verilerin analizi için bağımsız örneklem T-testi ve ANOVA testi kullanılmıştır.

\section{Araştırmanın Bulguları}

Acentaların kullanmış oldukları Instagram hesapları içerik analiz ile incelenmiştir. Instagram hesaplarının genel görünümü ile ilgili bilgiler Tablo 1'de yer almaktadır. İçerik analizi ile birlikte işletmelerin paylaşım yaptığı tüm gönderiler 14.04.2020 ile 05.05.2020 tarihleri arasında incelenmiştir.

Tablo 1: Acentaların Instagram Hesaplarının Genel Görünümü

\begin{tabular}{|c|c|c|c|c|c|c|c|c|}
\hline \multirow[b]{2}{*}{ NO } & \multicolumn{8}{|c|}{ GENEL GÖRÜNÜM } \\
\hline & 矛 & 氞 & 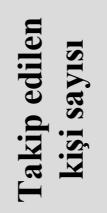 & 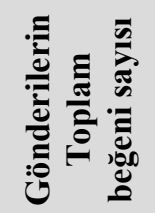 & 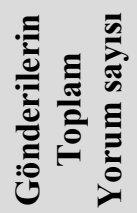 & 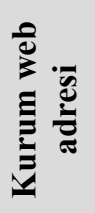 & 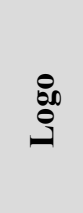 & ॠ্ \\
\hline$\overline{A 1}$ & 304 & 2688 & 44 & 48.908 & 1668 & Var & Var & $\overline{\text { Var }}$ \\
\hline$\overline{A 2}$ & 246 & 6332 & 2828 & 13.750 & 331 & Var & Var & Yok \\
\hline A3 & 641 & 19500 & 2524 & 133.234 & 5122 & Var & Var & Var \\
\hline A4 & 153 & 7136 & 2467 & 13.767 & 133 & Var & Var & Yok \\
\hline A5 & 67 & 761 & 3 & 4.688 & 108 & Var & Var & Yok \\
\hline A6 & 167 & 794 & 624 & 12.029 & 78 & Var & Var & Yok \\
\hline A7 & 3983 & 9508 & 22 & 1.136 .283 & 2637 & Var & Var & Yok \\
\hline A8 & 26 & 947 & 619 & 2.056 & 55 & Yok & Var & Yok \\
\hline A9 & 24 & 64 & 243 & 438 & 14 & Var & Yok & Yok \\
\hline A10 & 25 & 5006 & 14 & 354 & 15 & Yok & Var & Yok \\
\hline A11 & 893 & 3062 & 1204 & 111.222 & 574 & Var & Var & Var \\
\hline A12 & 931 & 24100 & 748 & 355.370 & 6428 & Var & Var & Yok \\
\hline A13 & 58 & 690 & 34 & 2.444 & 37 & Var & Var & Yok \\
\hline A14 & 732 & 5426 & 5 & 73.182 & 749 & Var & Var & Yok \\
\hline A15 & 53 & 828 & 3 & 4.610 & 45 & Yok & Var & Yok \\
\hline$\overline{A 16}$ & 735 & 8191 & 7145 & 69.292 & 8325 & Var & Var & Yok \\
\hline A17 & 153 & 1024 & 2751 & 3.964 & 97 & Var & Yok & Yok \\
\hline A18 & 618 & 6497 & 7243 & 33.063 & 867 & Var & Var & Yok \\
\hline A19 & 16 & 137 & 1 & 152 & 0 & Var & Var & Yok \\
\hline A20 & 576 & 5889 & 55 & 83.346 & 1758 & Var & Var & Yok \\
\hline A21 & 35 & 5856 & 2 & 1.754 & 58 & Var & Var & Var \\
\hline A22 & 61 & 1832 & 1304 & 1.782 & 19 & Var & Var & Yok \\
\hline
\end{tabular}




\begin{tabular}{|l|c|c|c|c|c|c|c|c|}
\hline A23 & 362 & 1963 & 20 & 7.647 & 542 & Var & Var & Var \\
\hline A24 & 233 & 1765 & 434 & 5.518 & 94 & Var & Var & Var \\
\hline A25 & 432 & 1305 & 598 & 35.328 & 289 & Var & Var & Yok \\
\hline A26 & $\mathbf{7 1 7}$ & $\mathbf{1 6 9 0 0}$ & 6474 & 277.263 & $\mathbf{9 7 8 5}$ & Var & Var & Yok \\
\hline A27 & 365 & 12800 & 3905 & 61.173 & 607 & Var & Var & Var \\
\hline A28 & 182 & 11200 & 8 & 22.896 & 429 & Yok & Var & Var \\
\hline A29 & 167 & 1731 & 1434 & 5.878 & 128 & Var & Var & Yok \\
\hline A30 & 326 & 11300 & 6957 & 17.155 & 311 & Var & Var & Yok \\
\hline TOPLAM & $\mathbf{1 3 2 8 1}$ & $\mathbf{1 7 5 2 3 2}$ & $\mathbf{4 9 7 1 3}$ & $\mathbf{2 5 3 8 5 4 6}$ & $\mathbf{4 1 3 0 3}$ & & & \\
\hline
\end{tabular}

Yapılan analiz sonucunda 3983 gönderi ile A7 işletmesi, paylaşım yapan acentalar arasında ilk sırada yer alırken bunu A12 işletmesi 931 gönderi ile ve A11 işletmesi 893 gönderi ile takip etmektedir. İşletmelerin takipçi sayıları analiz edildiğinde ilk sırada 24100 takipçi ile A12 işletmesi gelmektedir. Tüketiciler tarafından gönderilere yapılmış olan yorumlar dikkate alındığında en çok yoruma sahip olan işletme 1.136.283 yorum ile birlikte A7 işletmesidir. İşletmelerin çoğunluğu "Instagram" hesaplarında ürün ya da hizmetleri ile ilgili bilgilendirmelerin daha detaylı olduğu web sitelerinin adreslerini bulundurmaktadır. Ancak A8, A10, A15, A28 işletmeleri kurumsal web sitelerini "Instagram" hesaplarında paylaşmamışlardır. Kurumsal kimliği ifade eden logo ise işletmelerin çoğunluğu tarafından kullanılırken; A9 ve A17 işletmeleri tarafından logo kullanılmamaktadır. Tüketicilerde işletmeler ile ilgili çağrışım yapacak olan slogan ise 8 işletme tarafından kullanılırken diğer işletmelerin herhangi bir sloganı "Instagram" hesaplarında yer almamaktadır.

Tablo 2: İşletmelerin Instagramdaki Gönderi İçerikleri, Gönderi Türü ve Gönderi Yükleme Sıklığı

\begin{tabular}{|c|c|c|}
\hline GÖNDERİ İÇERÍKLERİ & Frekans & Yüzde \\
\hline Ürün & 7175 & 54,82 \\
\hline Promosyon & 115 & 0,88 \\
\hline Reklam & 1423 & 10,87 \\
\hline Sosyal Sorumluluk & 34 & 0,26 \\
\hline Özel Gün & 344 & 2,63 \\
\hline Çalışma Alanı & 250 & 1,91 \\
\hline Tüketici Tarafindan Oluşan İçerik & 3748 & 28,63 \\
\hline TOPLAM & 13089 & 100 \\
\hline GÖNDERİ TÜRÜ & Frekans & Yüzde \\
\hline Fotoğraf & 10823 & 91,59 \\
\hline Video & 994 & 8,41 \\
\hline TOPLAM & 11817 & 100 \\
\hline GÖNDERİ YÜKLEME SIKLIĞI & Frekans & Yüzde \\
\hline Hafta içi & 8841 & 66,55 \\
\hline Hafta sonu & 4443 & 33,45 \\
\hline TOPLAM & 13284 & 100 \\
\hline
\end{tabular}

Tablo 2'de işletmelerin "Instagramda" paylaşım yaptıkları gönderi içerikleri yer almaktadır. İşletmelerin yapmış olduğu gönderilerin \%54.82'sini ürünler oluştururken; 
\%28,63'ünü ise tüketici tarafından oluşan içerikler oluşturmaktadır. İşletmelerin paylaştıkları gönderilerin çoğunluğunu ürünler oluşturmakta, bunun yanında işletmelerin "Instagram" hesaplarını tüketiciye karşı ürünlerin tanıtılmasında kullandıkları sonucuna ulaşılmaktadır. İşletmelerin yapmış oldukları gönderi türü incelendiğinde \%91,59 kısmı fotoğraf paylaşımı yaparken; \%8,41'i ise video paylaşımı yapmaktadır. Buna ek olarak, işletmelerin yapmış oldukları paylaşımların \%66,55'i hafta içi yapılmışken; \%33,45'i ise hafta sonu yapılmıştır.

İşletmelerin yapmış olduğu paylaşımları ön plana çıkarmada kolaylık sağlayan "hashtag", marka farkındalığının oluşturulmasında kullanılmaktadır. Yapılan çalışmada tüm işletmelerin yapmış oldukları paylaşımlarda hem ürünle ilgili hem de işletme adında "hashtag" kullandığı sonucuna ulaşılmıştır. Buna ilişkin veriler Tablo 3’te yer almaktadır.

Tablo 3: İşletmelerin Hashtag Kullanımı, Marka Promosyon Durumu, Ürün Tanıtımı, Web Sitesine Bağlanma ve Yapılan Yorumlara Cevap Verme

\begin{tabular}{|c|c|c|c|c|}
\hline HASHTAG KULLANIMI & \multicolumn{2}{|c|}{ Frekans } & \multicolumn{2}{|c|}{ Yüzde } \\
\hline Hashtag kullanım & \multicolumn{2}{|c|}{30} & \multicolumn{2}{|c|}{38,46} \\
\hline Hashtag Marka İsmi & \multicolumn{2}{|l|}{30} & \multicolumn{2}{|c|}{38,46} \\
\hline Mention Kullanımı (@) & \multicolumn{2}{|l|}{18} & \multicolumn{2}{|c|}{23,08} \\
\hline TOPLAM & \multicolumn{2}{|l|}{78} & \multicolumn{2}{|c|}{100} \\
\hline \multirow{2}{*}{ MARKA PROMOSYON DURUMU } & \multicolumn{2}{|c|}{ Evet } & \multicolumn{2}{|c|}{ Hayır } \\
\hline & Frekans & Yüzde & Frekans & Yüzde \\
\hline & 13 & 43,33 & 17 & 56,67 \\
\hline TOPLAM & \multicolumn{2}{|c|}{30} & \multicolumn{2}{|c|}{100} \\
\hline \multirow{3}{*}{ ÜRÜN TANITIMI } & \multicolumn{2}{|c|}{ Evet } & \multicolumn{2}{|c|}{ Hayır } \\
\hline & Frekans & Yüzde & Frekans & Yüzde \\
\hline & 23 & 76,67 & 7 & 23,33 \\
\hline TOPLAM & \multicolumn{2}{|c|}{30} & \multicolumn{2}{|c|}{100} \\
\hline \multirow{3}{*}{ WEB ADRESİ BAĞLANTISI } & \multicolumn{2}{|c|}{ Evet } & \multicolumn{2}{|c|}{ Hayır } \\
\hline & Frekans & Yüzde & Frekans & Yüzde \\
\hline & 11 & 36,67 & 19 & 63,33 \\
\hline TOPLAM & \multicolumn{2}{|c|}{30} & \multicolumn{2}{|c|}{100} \\
\hline \multirow{3}{*}{$\begin{array}{l}\text { YAPILAN YORUMLARA CEVAP } \\
\text { VERME }\end{array}$} & \multicolumn{2}{|c|}{ Evet } & \multicolumn{2}{|c|}{ Hayır } \\
\hline & Frekans & Yüzde & Frekans & Yüzde \\
\hline & 16 & 53,33 & 14 & 46,67 \\
\hline TOPLAM & \multicolumn{2}{|c|}{30} & \multicolumn{2}{|c|}{100} \\
\hline
\end{tabular}

Tablo 3'e göre tüm işletmelerin kendi adlarını da "hashtag" ile kullanması, marka farkındalığı oluşturulmasında önemli bir etmen olarak görülmektedir. İşletmelerin 18 tanesi “mention" kullanırken; 12 tane işletme “mention” kullanmamaktadır. İşletmelerin \%56,67'si

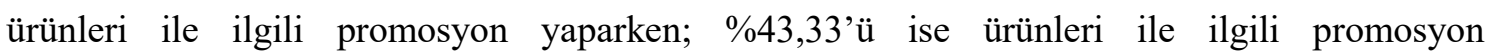
uygulamamaktadır. İşletmelerin \%76,67'si ürünlerinin tanıtımı için "Instagramı" kullanırken; $\% 23,33$ 'ü ise ürün tanıtımı yapmamaktadır. İşletmelerin paylaştıkları gönderilerde \%63,33’ünde "web sitesine" bağlantı verilmezken; \%36,67'si ise paylaşımlarında “web adresi” bağlantısı 
kullanmaktadır. Tüketiciler tarafindan yapılmış olan yorumlara; işletmelerin $\% 53,33$ 'ü cevap verirken, \%46,67'si ise cevap vermemektedir.

Tablo 4'te tüketicilerin işletmeler tarafindan paylaşılan gönderilere yapmış oldukları yorumların özellikleri incelenmiştir. Yapılan yorumların \%46,65'i farklı tüketicilerin etiketlenmesini oluştururken; \%31,36's1 "emoji” oluşturmaktadır. Yapılan yorumlara işletme tarafindan verilen cevaplar incelendiğinde ise \%62,57'sini açıklama oluştururken; \%23,06'sını ise "emoji”" oluşturmaktadır.

Tablo 4: Yapılan Yorumların ve Yoruma Verilen Cevabın Özellikleri

\begin{tabular}{|l|c|c|}
\hline \multicolumn{1}{|c|}{ YAPILAN YORUMLARIN ÖZELLIKLERI } & Frekans & Yüzde \\
\hline İstek & 168 & 0,41 \\
\hline Şikayet & 414 & 1 \\
\hline Eleştiri & 124 & 0,3 \\
\hline Soru & 1506 & 3,65 \\
\hline Cevap & 1253 & 3,03 \\
\hline Emoji & 12953 & 31,36 \\
\hline Beğeni belirtme & 5620 & 13,61 \\
\hline Etiketleme & 19267 & 46,65 \\
\hline Toplam & $\mathbf{4 1 3 0 3}$ & $\mathbf{1 0 0}$ \\
\hline YORUMLARA VERİLEN CEVABIN ÖZELLIKLERI & Frekans & Yüzde \\
\hline Açklama & 784 & 62,57 \\
\hline Müşteri temsilcilerine yönlendirme & 180 & 14,37 \\
\hline Emoji birakma & 289 & 23,06 \\
\hline Toplam & $\mathbf{1 2 5 3}$ & $\mathbf{1 0 0}$ \\
\hline
\end{tabular}

Tablo 5'te işletmeler tarafından paylaşım yapılmış olan gönderilerin altına yazılan metin özellikleri incelenmiştir. Gönderilerin metin özelliklerinin \%33,2'si söyleşi iken; \%26,09’u ürün ile ilgili açıklama ve \% 22,01'i ise ürünle ilgili "hashtag" kullanımı oluşturmaktadır.

Tablo 5: Fotoğrafın Altında Kullanılan Metnin Özellikleri

\begin{tabular}{|l|c|c|}
\hline \multicolumn{2}{|c|}{ FOTOĞRAFIN ALTINDA KULLANILAN METNIN ÖZELLIKLERI } \\
\hline & Frekans & Yüzde \\
\hline Açıklama & 2716 & 26,09 \\
\hline Tavsiye & 351 & 3,37 \\
\hline Söyleşi & 3456 & 33,2 \\
\hline Soru cevap & 22 & 0,21 \\
\hline Yönlendirme & 213 & 2,05 \\
\hline Tanitım & 638 & 6,13 \\
\hline Hasthtag kullanımı & 2291 & 22,01 \\
\hline Bilgilendirme & 723 & 6,95 \\
\hline TOPLAM & $\mathbf{1 0 4 1 0}$ & $\mathbf{1 0 0}$ \\
\hline
\end{tabular}

Rize ili seyahat acentalarında çalışan personellerin sosyal medya pazarlamasına yönelik alg1 ve tutumlarının belirlenmesinde yapılan nicel araştırma sonuçları aşağıdaki şekildedir. Aşağıda Tablo 6'da seyahat acentalaları ve çalışanlarına ilişkin demografik verilere yer 
verilmiştir. Araştırmaya katılan katılımcıların \%73,3'ünü erkekler ve \%80'ini 21-40 yaş arasında olan katılımcılar oluşturmaktadır. Katılımcıların \%33,3’ü lise, \%30’u ise lisans eğitim düzeyine sahiptirler. Katılımcıların \%53,3'ü işletme sahibidir. İşletmelerin \%50’si 1-3 y1l arasında, \%30'u ise 4-9 yıl arasında faaliyet göstermektedir. Çalışmaya katılan acentalar sektördeki diğer acentalarla kendilerini kıyasladığında \%40’1 kendi acentasını küçük olarak görmektedir. Acentalar rakiplerinin \%53,3'ünün yurtiçinden, misafirlerinin ise \%53,3'ünün hem yurtiçinden hem de yurtdışından olduğunu belirtmişlerdir.

Tablo 6: Seyahat Acentaları ve Çalışanına İlişkin Demografik Bilgiler

\begin{tabular}{|c|c|c|c|c|c|}
\hline Değișken Grupları & (f) & $\%$ & Değişken Grupları & (f) & $\%$ \\
\hline $\begin{array}{l}\text { Cinsiyet } \\
\text { Kadın } \\
\text { Erkek }\end{array}$ & $\begin{array}{c}8 \\
22\end{array}$ & $\begin{array}{l}26,7 \\
73,3\end{array}$ & $\begin{array}{l}\text { Yaş } \\
21-40 \\
41-55\end{array}$ & $\begin{array}{c}24 \\
6 \\
\end{array}$ & $\begin{array}{l}80 \\
20 \\
\end{array}$ \\
\hline $\begin{array}{l}\text { Eğitim } \\
\text { Lise } \\
\text { Önlisans } \\
\text { Lisans } \\
\text { Lisansüstü }\end{array}$ & $\begin{array}{l}10 \\
5 \\
9 \\
6\end{array}$ & $\begin{array}{l}33,3 \\
16,7 \\
30 \\
20\end{array}$ & $\begin{array}{l}\text { İssletmede ki Görev } \\
\text { İşletme sahibi } \\
\text { Genel Müdür } \\
\text { Hem işletme Sahibi hem de Genel Müdür } \\
\text { Operasyon Müdürü } \\
\text { Rezervasyon Sorumlusu }\end{array}$ & $\begin{array}{l}16 \\
3 \\
6 \\
3 \\
2\end{array}$ & $\begin{array}{c}53,3 \\
10 \\
20 \\
\\
10 \\
6,7\end{array}$ \\
\hline $\begin{array}{l}\text { İşletme Faaliyet Süresi } \\
1 \text { ylldan az } \\
1-3 \text { y1l } \\
4-9 \text { y1l } \\
10 \text { yil ve üzeri }\end{array}$ & $\begin{array}{c}3 \\
15 \\
9 \\
3 \\
\end{array}$ & $\begin{array}{l}10 \\
50 \\
30 \\
10 \\
\end{array}$ & $\begin{array}{lll}\text { Diğer Acentalara } & \text { Göre } & \text { Büyüklük } \\
\text { Klyaslaması } & & \\
\text { Küçük } & & \\
\text { Orta } & & \\
\text { Büyük } & & \\
\end{array}$ & $\begin{array}{l}12 \\
17 \\
1 \\
\end{array}$ & $\begin{array}{l}40 \\
56,7 \\
3,3 \\
\end{array}$ \\
\hline $\begin{array}{l}\text { Rakiplerin Bulunduğu Pazar } \\
\text { Yurtiçi } \\
\text { Yurtdışı } \\
\text { Her İkisi de }\end{array}$ & $\begin{array}{c}16 \\
3 \\
11\end{array}$ & $\begin{array}{c}53,3 \\
10 \\
36,7\end{array}$ & $\begin{array}{l}\text { Müşterilerin Bulunduğu Pazar } \\
\text { Yurtiçi } \\
\text { Yurtdiş1 } \\
\text { Her İkisi de }\end{array}$ & $\begin{array}{c}12 \\
2 \\
16\end{array}$ & $\begin{array}{r}40 \\
6,7 \\
53,3\end{array}$ \\
\hline
\end{tabular}

Çalışmaya katılan acentaların tümünün sosyal medya hesabı bulunmaktadır. Çalışmaya katılan acentaların \%90'1 sosyal medya pazarlaması kullanırken \%10'u ise sosyal medya pazarlaması kullanmamaktadır. Sosyal medya pazarlamasını kullanmama sebepleri arasında ise sosyal medya aracılığı ile müşterilere ulaşılacağının düşünülmemesi ve pazarlama için sosyal medyanın güvenilir bulunmadığı yer almaktadır. Seyahat acentalarının \%43,3’ü 1-2 yıl arasında sosyal medya hesabı kullanmakta iken, acentaların \%40'1 haftalık 1-5 saatini sosyal medya pazarlamasına harcamaktadırlar.

Sosyal medya pazarlaması kullanan acentaların \%66,7'si sosyal medya pazarlaması ile ilgili herhangi bir eğitim almamışlardır. İşletmelerin kullandığı sosyal medya hesap güncellemelerinin \%50'sini işyeri personeli yapmaktadır. Acentaların \%46,7'si, sosyal medya pazarlamasının işletmeye sağladığı en önemli faydanın, şirketin tanınmasına katkı sağladığı şeklinde belirtmiş; sosyal medya platformlarını kullanma nedenleri arasında ise \%40'ı farklı 
içerikler paylaşarak müşterinin dikkatini çekmek olduğunu belirtmişlerdir. İşletmelerin \%20,6's1 pazarlama aracı olarak sosyal medya araçlarını, \%17,6'sı websitesini, \%15,3'ü basılı tanıtım materyalini kullanmakta iken; sosyal medya pazarlaması için \%31'i "Facebook", \%31'i "Instagram" platformunu kullanmaktadırlar.

Seyahat acentalarının sosyal medya pazarlamasına yönelik durumları aşağıda Tablo 7'de verilmiştir.

Tablo 7: Seyahat Acentalarının Sosyal Medya Pazarlamasına Yönelik Durumları

\begin{tabular}{|c|c|c|c|c|c|}
\hline $\begin{array}{lcc}\text { Sosyal Medya } & \text { Pazarlamasına } \\
\text { Yönelik Durumlar } & \\
\end{array}$ & (f) & $\%$ & $\begin{array}{l}\text { Sosyal Medya Pazarlamasına Yönelik } \\
\text { Durumlar }\end{array}$ & (f) & $\%$ \\
\hline $\begin{array}{l}\text { Sosyal Medya Hesabınız Var mı? } \\
\text { Evet } \\
\text { Hayır }\end{array}$ & $\begin{array}{l}30 \\
0\end{array}$ & $\begin{array}{l}100 \\
0\end{array}$ & $\begin{array}{l}\text { Sosyal Medya Pazarlaması Yapıyor } \\
\text { musunuz? } \\
\text { Evet } \\
\text { Hayır }\end{array}$ & $\begin{array}{l}27 \\
3\end{array}$ & $\begin{array}{l}90 \\
10\end{array}$ \\
\hline $\begin{array}{l}\text { İşletmede Kullanılan Sosyal Medya } \\
\text { Araçları } \\
\text { Facebook } \\
\text { Youtube } \\
\text { Instagram } \\
\text { Blog } \\
\text { Twitter } \\
\text { Foursquare }\end{array}$ & $\begin{array}{l}27 \\
15 \\
27 \\
5 \\
9 \\
4\end{array}$ & $\begin{array}{l}31 \\
17,2 \\
31 \\
5,7 \\
10,3 \\
4,6\end{array}$ & $\begin{array}{l}\text { Sosyal Medya Pazarlaması İçin } \\
\text { Ayrılan Haftalık Süre } \\
1 \text { saatten az } \\
1-5 \text { saat } \\
6-10 \text { saat } \\
11 \text { saatten fazla }\end{array}$ & $\begin{array}{l}4 \\
12 \\
5 \\
6\end{array}$ & $\begin{array}{l}13,3 \\
40 \\
16,7 \\
20\end{array}$ \\
\hline $\begin{array}{l}\text { Sosyal Medya Kullanma Süresi } \\
1 \text { y1ldan az } \\
1-2 \text { yil } \\
3-5 \text { yil } \\
5 \text { yildan daha fazla }\end{array}$ & $\begin{array}{l}2 \\
13 \\
6 \\
6\end{array}$ & $\begin{array}{l}6,7 \\
43,3 \\
20 \\
20\end{array}$ & $\begin{array}{l}\text { Sosyal Medya Pazarlaması Eğitim } \\
\text { Durumu } \\
\text { Evet } \\
\text { Hayır }\end{array}$ & $\begin{array}{l}7 \\
20\end{array}$ & $\begin{array}{l}23,3 \\
66,7\end{array}$ \\
\hline $\begin{array}{l}\text { Sosyal Medya Güncellemelerini } \\
\text { Yapan Kişi } \\
\text { İşyeri sahibi } \\
\text { İşyeri personeli } \\
\text { Dışarıdan uzmanlar tarafından }\end{array}$ & $\begin{array}{l}10 \\
15 \\
2\end{array}$ & $\begin{array}{l}33,3 \\
50 \\
6,7\end{array}$ & $\begin{array}{l}\text { Sosyal Medya Pazarlamasının } \\
\text { Sağladığı Fayda } \\
\text { Şirketin tanınmasını sağlamak } \\
\text { Şirkete ait web sitesin yoğunluğunu } \\
\text { artırmak } \\
\text { Şirkete ait sadık müşteriler kazanmak } \\
\text { Satışları artırmak }\end{array}$ & $\begin{array}{l}14 \\
1 \\
2 \\
10\end{array}$ & $\begin{array}{l}46,7 \\
3,3 \\
6,7 \\
33,3\end{array}$ \\
\hline $\begin{array}{l}\text { Sosyal Medyayı Kullanma Amacı } \\
\text { Şirket ile ilgili ana bilgileri paylaşmak } \\
\text { Şirket ile ilgili video veya fotoğraf } \\
\text { paylaşmak } \\
\text { Müşteri ile iletişim kurmak } \\
\text { Farklı içerikler paylaşarak müşterinin } \\
\text { dikkatini çekmek }\end{array}$ & $\begin{array}{l}4 \\
12\end{array}$ & $\begin{array}{l}3,3 \\
33,3 \\
13,3 \\
40\end{array}$ & $\begin{array}{l}\text { İşletmede kullanılan } \\
\text { Araçları } \\
\text { TV ve radyo } \\
\text { Basılı tanıtım Materyali } \\
\text { Gazete ve dergi } \\
\text { Fuar ve Sergiler } \\
\text { Websitesi } \\
\text { Billboardlar } \\
\text { E-posta } \\
\text { Sosyal Medya araçları } \\
\text { Diğer müşteriler aracılığıyla }\end{array}$ & $\begin{array}{l}3 \\
20 \\
18 \\
8 \\
23 \\
9 \\
6 \\
27 \\
17\end{array}$ & $\begin{array}{l}2,3 \\
15,3 \\
13,7 \\
6,1 \\
17,6 \\
6,9 \\
4,6 \\
20,6 \\
13\end{array}$ \\
\hline
\end{tabular}

Aşağıda Tablo 8'e göre; katılımcılar tarafindan “Sosyal medya kullanımı oldukça esnek ve rahattır." $(\mathrm{x}=4,48)$, "Sosyal medya sayesinde müşterilere kolaylıkla erişim sağlanmaktadır." $(\mathrm{x}=4,51)$, "Sosyal medya sayesinde müşteriler ile etkileşim artışı sağlanmaktadır." $(x=4,48)$, 


\section{Elif ACUNER, Kübra KÜÇÜK}

\section{Rize İli Seyahat Acentalarının Sosyal Medya Pazarlamasına Yönelik Algı ve Tutumları}

"Sosyal medya sayesinde müşterilere birden fazla seyahat hizmetleri sunulmaktadır." $(x=4,51)$ yargılarıyla sosyal medya pazarlamasına yönelik olumlu tutum sergilenmektedir. "Sosyal medya potansiyel müşterilerin şirkete karşı yabancılaşmasına neden olmaktadır." ( $\mathrm{x}=1,81)$, "Sosyal medyada şirketin ürünlerini etkin şekilde pazarlamak oldukça zordur." $(x=2,03)$, "Sosyal medyada müşterilerin ve satışların kayıtlarını güncel tutmak oldukça zordur." (x=2,03), "Sosyal medya da ürünleri etkili şekilde pazarlamak zordur.” $(x=2,07)$ gibi sosyal medya pazarlamasına yönelik olumsuz yargıları ise katılımcılar onaylamamaktadır.

Tablo 8: İşletmelerin Sosyal Medya Pazarlamasına Yönelik Tutumları

\begin{tabular}{|c|c|c|c|c|c|c|c|}
\hline Yargilar & 递 & 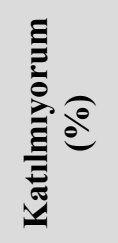 & 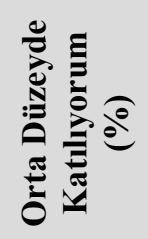 & 氡 & 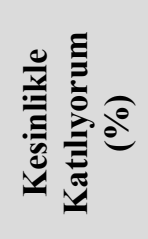 & $\mathbf{x}$ & s.s \\
\hline $\begin{array}{l}\text { Sosyal medya kullanımı oldukça esnek } \\
\text { ve rahattır. }\end{array}$ & 3,3 & 0 & 3,3 & 29,6 & 63,0 & 4,48 & 0,89 \\
\hline $\begin{array}{l}\text { Sosyal medya sayesinde müssterilere } \\
\text { kolaylıkla erişim sağlanmaktadır. }\end{array}$ & 3,3 & 0 & 3,7 & 25,9 & 66,7 & 4,51 & 0,89 \\
\hline $\begin{array}{l}\text { Sosyal medya sayesinde pazarlama } \\
\text { maliyetleri azaltmaktadır. }\end{array}$ & 3,7 & 11,1 & 3,7 & 40,7 & 40,7 & 4,03 & 1,12 \\
\hline $\begin{array}{l}\text { Sosyal medya sayesinde müşteriler ile } \\
\text { etkileşim artışı sağlanmaktadır. }\end{array}$ & 3,7 & 0 & 3,7 & 29,6 & 63,0 & 4,48 & 0,89 \\
\hline $\begin{array}{l}\text { Sosyal medya sayesinde müsteri } \\
\text { portföyünü hedeflemek ve tanımlamak } \\
\text { daha kolaydır. }\end{array}$ & 3,3 & 0 & 6,7 & 36,7 & 43,3 & 4,29 & 0,91 \\
\hline \begin{tabular}{l}
\multicolumn{3}{l}{$\begin{array}{l}\text { Sosyal medyada iletişim esnasında insan } \\
\text { temas1 ve güven } \\
\text { hissedilmektedir. }\end{array}$} & \\
eksikliği \\
\end{tabular} & 13,3 & 20,0 & 16,7 & 26,7 & 13,3 & 3,07 & 1,32 \\
\hline $\begin{array}{lccc}\begin{array}{l}\text { Sosyal } \\
\text { küreselleşmektedir } \\
\text { oluşturmaktadır. }\end{array} & \text { ve } & \text { vesinde } & \text { ürünler } \\
\text { pazarlar }\end{array}$ & 6,7 & 0 & 13,3 & 33,3 & 36,7 & 4,03 & 1,12 \\
\hline $\begin{array}{l}\text { Sosyal medyada yüz yüze } \text { satı̧s } \\
\text { esnasında sunulan } \\
\text { hissedilmektedir. }\end{array}$ & 10,0 & 13,3 & 26,7 & 26,7 & 13,3 & 3,22 & 1,21 \\
\hline $\begin{array}{l}\text { Sosyal medya da güvenlik sorunları yer } \\
\text { almaktadır. }\end{array}$ & 20,0 & 6,7 & 23,3 & 26,7 & 13,3 & 3,07 & 1,38 \\
\hline $\begin{array}{l}\text { Sosyal medyada kişiye özel ürünler } \\
\text { yerine standart ürünler satılmaktadır. }\end{array}$ & 33,3 & 20 & 20 & 10 & 6,7 & 2,29 & 1,29 \\
\hline $\begin{array}{l}\text { Sosyal medya potansiyel müşterilerin } \\
\text { şirkete karş1 yabancılaşmasına neden } \\
\text { olmaktadır. }\end{array}$ & 50 & 23,3 & 3,3 & 10,0 & 3,3 & 1,81 & 1,17 \\
\hline $\begin{array}{l}\text { Sosyal medyada şirketin ürünlerini etkin } \\
\text { șekilde pazarlamak oldukça zordur. }\end{array}$ & 46,7 & 16,7 & 10 & 10 & 6,7 & 2,03 & 1,34 \\
\hline $\begin{array}{l}\text { Sosyal medyada } \\
\text { satışların kayitlarısterilerin } \\
\text { oldukça zordur. }\end{array}$ & 40 & 23,3 & 13,3 & 10 & 3,3 & 2,03 & 1,19 \\
\hline 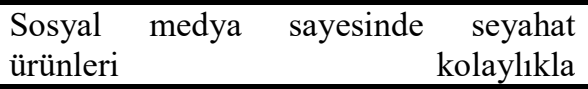 & 3,3 & 0 & 14,8 & 33,3 & 48,1 & 4,22 & 0,97 \\
\hline
\end{tabular}




\begin{tabular}{|c|c|c|c|c|c|c|c|}
\hline Yargilar & 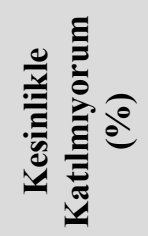 & 音 & 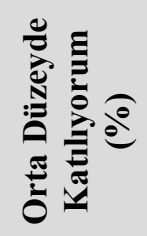 & 绨 & 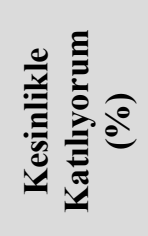 & $\mathbf{x}$ & s.s \\
\hline \multicolumn{8}{|l|}{ pazarlanabilmektedir. } \\
\hline $\begin{array}{lccc}\begin{array}{l}\text { Sosyal } \\
\text { birden } \\
\text { sunulmaktadır. }\end{array} & \begin{array}{c}\text { sayesinde } \\
\text { seyahat }\end{array} & \begin{array}{c}\text { müssterilere } \\
\text { hizmetleri }\end{array} \\
\end{array}$ & 3,3 & 0 & 3,3 & 23,3 & 60 & 4,51 & 0,89 \\
\hline $\begin{array}{l}\text { Sosyal medya sayesinde rakip firmalar } \\
\text { kolaylıkla takip edilir ve değişikliklere } \\
\text { uyum sağlanır. }\end{array}$ & 3,3 & 0 & 3,3 & 33,3 & 50 & 4,40 & 0,88 \\
\hline $\begin{array}{l}\text { Sosyal medya sayesinde gelecek } \\
\text { zamanda pazarlama için kullanılacak } \\
\text { olan müşteri bilgileri elde edilmektedir. }\end{array}$ & 3,3 & 3,3 & 3,3 & 50 & 30 & 4,11 & 0,93 \\
\hline $\begin{array}{l}\text { Sosyal medya uluslararası pazarlama ve } \\
\text { satış kolaylığı sağlamaktadır. }\end{array}$ & 3,3 & 0 & 3,3 & 50 & 33,3 & 4,25 & 0,97 \\
\hline $\begin{array}{ll}\text { Sosyal medya işletmede } \\
\text { maliyetini azaltmaktadır. }\end{array}$ & 3,3 & 13,3 & 10 & 23,3 & 40 & 3,92 & 1,23 \\
\hline 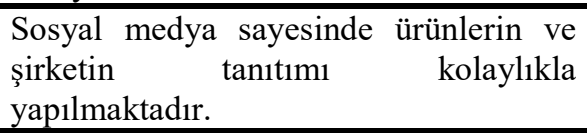 & 3,3 & 0 & 3,3 & 36,7 & 46,7 & 4,37 & 0,88 \\
\hline $\begin{array}{l}\text { Sosyal medya satış sürecini ve hizmet } \\
\text { sunumunu standartlaştırmaktadır. }\end{array}$ & 6,7 & 20 & 23,3 & 23,3 & 16,7 & 3,25 & 1,22 \\
\hline $\begin{array}{l}\text { Sosyal medya da ürünleri etkili şekilde } \\
\text { pazarlamak zordur. }\end{array}$ & 36,7 & 30 & 10 & 6,7 & 6,7 & 2,07 & 1,23 \\
\hline $\begin{array}{l}\text { Tedarikçiler ve tüketiciler e-ticaret için } \\
\text { yetersizdirler. }\end{array}$ & 23,3 & 26,7 & 16,7 & 20 & 3,3 & 2,48 & 1,22 \\
\hline $\begin{array}{l}\text { Sirkette sosyal medya için } \\
\text { uzmanlık eksiğimiz mevcuttur. }\end{array}$ & 23,3 & 6,7 & 10 & 33,3 & 16,7 & 3,14 & 1,51 \\
\hline $\begin{array}{lcr}\text { Sosyal medya } & \text { kullanımının } \\
\text { başlangıcında } & \text { yüksek } & \text { maliyetler } \\
\text { gereklidir. } & & \\
\end{array}$ & 26,7 & 40 & 3,3 & 13,3 & 6,7 & 2,25 & 1,25 \\
\hline $\begin{array}{l}\text { Sosyal medya kullanımı stratejileri ile } \\
\text { ilgili isletmelere tavsiye eksikliği yer } \\
\text { almaktadır. }\end{array}$ & 10 & 13,3 & 16,7 & 30 & 20 & 3,40 & 1,30 \\
\hline $\begin{array}{l}\text { Sosyal medya önümüzde ki } 5-7 \text { yll } \\
\text { içerisinde turizm sektörünün iş yapma } \\
\text { şeklini değiştirecektir. }\end{array}$ & 3,3 & 3,3 & 16,7 & 33,3 & 33,3 & 4,0 & 1,03 \\
\hline
\end{tabular}

Çalışma kapsamında geliştirilen araştırma alt soruları T-testi ve ANOVA analiz yöntemleri ile test edilmiştir. Araştırma kapsamında geliştirilen ilk araştırma alt sorusu olan " 1 : Seyahat acentalarında çalışan personellerin demografik özellikleri ile sosyal medya pazarlamasına ilişkin tutumları arasında anlamlı bir farklılık var mıdır?" sorusu T-testi analizine tabi tutulmuştur. Analiz sonucuna göre $\mathrm{p}>0.05$ olduğu için araştırmanın ilk araştırma alt sorusuna ait herhangi bir anlamlı farklılığa rastlanmamıştır.

Araştırma kapsamında incelenen ikinci araştırma alt sorusu olan "2: İşletmenin sosyal medya eğitimi alma durumu ile sosyal medya kullanımı arasında anlamlı bir farklılık var 


\section{Rize İli Seyahat Acentalarının Sosyal Medya Pazarlamasına Yönelik Algı ve Tutumları}

mıdır?" sorusu yine T-testi yardımı ile analiz edilmiştir. T-testine ilişkin analiz sonuçları aşağıda Tablo 9'da yer almaktadır.

Tablo 9'da yer alan analiz sonucuna göre $\mathrm{p}<0.05$ olduğundan dolayı ikinci araştırma alt sorusuna ilişkin istatistiksel anlamlı bir farklılığa rastlanmıştır. Dolayısıyla sosyal medya kullanımının esnek ve rahat olması için eğitim alan katılımcılar ile herhangi bir eğitim almayan katılımcı arasında anlamlı bir farklı1ık bulunmaktadır.

Tablo 9: İşletmelerin Sosyal Medya Pazarlama Eğitimi Alma Durumuna Göre Sosyal Medya Pazarlamasına Yönelik Tutumlarının T-testi Sonuçları

\begin{tabular}{|c|c|c|c|c|c|c|}
\hline Yargilar & $\begin{array}{l}\text { Eğitim } \\
\text { Alma } \\
\text { Durumu }\end{array}$ & $\mathbf{n}$ & $\mathbf{x}$ & S.S. & $\mathbf{t}$ & $\mathbf{p}$ \\
\hline Sosyal medya kullanımı oldukça esnek ve rahattır. & $\begin{array}{l}\text { Evet } \\
\text { Hayir }\end{array}$ & $\begin{array}{c}7 \\
20\end{array}$ & $\begin{array}{c}5 \\
4,3\end{array}$ & $\begin{array}{l}, 00 \\
, 97\end{array}$ & 3,19 & $0,05 *$ \\
\hline $\begin{array}{l}\text { Sosyal medya sayesinde müşterilere kolaylıkla erişim } \\
\text { sağlanmaktadır. }\end{array}$ & $\begin{array}{l}\text { Evet } \\
\text { Hayır }\end{array}$ & $\begin{array}{c}7 \\
20\end{array}$ & $\begin{array}{l}4,71 \\
4,45\end{array}$ & $\begin{array}{l}48 \\
, 99\end{array}$ & ,66 &, 511 \\
\hline $\begin{array}{l}\text { Sosyal medya sayesinde pazarlama maliyetleri } \\
\text { azaltmaktadır. }\end{array}$ & $\begin{array}{l}\text { Evet } \\
\text { Hayir }\end{array}$ & $\begin{array}{c}7 \\
20\end{array}$ & $\begin{array}{c}4,42 \\
3,9\end{array}$ & $\begin{array}{l}, 78 \\
1,20\end{array}$ & 1,07 & ,294 \\
\hline $\begin{array}{l}\text { Sosyal medya sayesinde müşteriler ile etkileşim artışı } \\
\text { sağlanmaktadır. }\end{array}$ & $\begin{array}{l}\text { Evet } \\
\text { Hayir }\end{array}$ & $\begin{array}{c}7 \\
20\end{array}$ & $\begin{array}{c}4,71 \\
4,4\end{array}$ & $\begin{array}{l}48 \\
, 99\end{array}$ & ,796 & ,434 \\
\hline $\begin{array}{l}\text { Sosyal medya sayesinde müşteri portföyünü hedeflemek } \\
\text { ve tanımlamak daha kolaydır. }\end{array}$ & $\begin{array}{l}\text { Evet } \\
\text { Hayır }\end{array}$ & $\begin{array}{c}7 \\
20\end{array}$ & $\begin{array}{l}4,71 \\
4,15\end{array}$ & $\begin{array}{l}48 \\
, 98\end{array}$ & 1,43 & ,16 \\
\hline $\begin{array}{l}\text { Sosyal medyada iletişim esnasında insan teması ve güven } \\
\text { eksikliği hissedilmektedir. }\end{array}$ & $\begin{array}{l}\text { Evet } \\
\text { Hayir }\end{array}$ & $\begin{array}{c}7 \\
20\end{array}$ & $\begin{array}{l}3,42 \\
2,95\end{array}$ & $\begin{array}{l}1,61 \\
1,23\end{array}$ & ,815 & ,423 \\
\hline $\begin{array}{l}\text { Sosyal medya sayesinde ürünler küreselleşmektedir ve } \\
\text { yeni pazarlar oluşturmaktadır. }\end{array}$ & $\begin{array}{l}\text { Evet } \\
\text { Hayır }\end{array}$ & $\begin{array}{c}7 \\
20\end{array}$ & $\begin{array}{c}4,71 \\
3,8\end{array}$ & $\begin{array}{c}, 48 \\
1,16\end{array}$ & 1,94 & 063 \\
\hline $\begin{array}{l}\text { Sosyal medyada yüz yüze satış esnasında sunulan } \\
\text { fursatların eksikliği hissedilmektedir. }\end{array}$ & $\begin{array}{l}\text { Evet } \\
\text { Hayır }\end{array}$ & $\begin{array}{c}7 \\
20\end{array}$ & $\begin{array}{c}3,57 \\
3,1\end{array}$ & $\begin{array}{l}1,39 \\
1,16\end{array}$ & ,876 & ,389 \\
\hline Sosyal medya da güvenlik sorunları yer almaktadır. & $\begin{array}{l}\text { Evet } \\
\text { Hayir }\end{array}$ & $\begin{array}{c}7 \\
20\end{array}$ & $\begin{array}{l}3,14 \\
3,05\end{array}$ & $\begin{array}{l}1,67 \\
1,31\end{array}$ &, 15 & ,882 \\
\hline $\begin{array}{l}\text { Sosyal medyada kişiye özel ürünler yerine standart } \\
\text { ürünler satılmaktadır. }\end{array}$ & $\begin{array}{l}\text { Evet } \\
\text { Hayir }\end{array}$ & $\begin{array}{c}7 \\
20\end{array}$ & $\begin{array}{l}2,71 \\
2,15\end{array}$ & $\begin{array}{l}1,88 \\
1,03\end{array}$ & ,751 & ,476 \\
\hline $\begin{array}{l}\text { Sosyal medya potansiyel müşterilerin şirkete karş1 } \\
\text { yabancılaşmasına neden olmaktadır. }\end{array}$ & $\begin{array}{l}\text { Evet } \\
\text { Hayir }\end{array}$ & $\begin{array}{c}7 \\
20\end{array}$ & $\begin{array}{l}2,28 \\
1,65\end{array}$ & $\begin{array}{l}1,6 \\
, 98\end{array}$ & 1,24 & ,226 \\
\hline $\begin{array}{l}\text { Sosyal medyada şirketin ürünlerini etkin şekilde } \\
\text { pazarlamak oldukça zordur. }\end{array}$ & $\begin{array}{l}\text { Evet } \\
\text { Hayir }\end{array}$ & $\begin{array}{c}7 \\
20\end{array}$ & $\begin{array}{c}2,42 \\
1,9\end{array}$ & $\begin{array}{l}1,81 \\
1,16\end{array}$ & ,892 & ,381 \\
\hline $\begin{array}{l}\text { Sosyal medyada müşterilerin ve satışların kayıtlarını } \\
\text { güncel tutmak oldukça zordur. }\end{array}$ & $\begin{array}{l}\text { Evet } \\
\text { Hayır }\end{array}$ & $\begin{array}{c}7 \\
20\end{array}$ & $\begin{array}{c}2,42 \\
1,9\end{array}$ & $\begin{array}{l}1,61 \\
1,02\end{array}$ & 1,01 & ,322 \\
\hline $\begin{array}{l}\text { Sosyal medya sayesinde seyahat ürünleri kolaylıkla } \\
\text { pazarlanabilmektedir. }\end{array}$ & $\begin{array}{l}\text { Evet } \\
\text { Hayır }\end{array}$ & $\begin{array}{c}7 \\
20\end{array}$ & $\begin{array}{c}5 \\
3,95\end{array}$ & $\begin{array}{l}, 00 \\
, 99\end{array}$ & 4,7 &, $00 *$ \\
\hline $\begin{array}{l}\text { Sosyal medya sayesinde müşterilere birden fazla seyahat } \\
\text { hizmetleri sunulmaktadır. }\end{array}$ & $\begin{array}{l}\text { Evet } \\
\text { Hayır }\end{array}$ & $\begin{array}{c}7 \\
20\end{array}$ & $\begin{array}{c}5 \\
4,35\end{array}$ & $\begin{array}{l}, 00 \\
, 98\end{array}$ & 1,71 & ,098 \\
\hline
\end{tabular}




\begin{tabular}{|c|c|c|c|c|c|c|}
\hline Yargilar & $\begin{array}{c}\text { Eğitim } \\
\text { Alma } \\
\text { Durumu }\end{array}$ & n & $\mathbf{x}$ & S.S. & $\mathbf{t}$ & $\mathbf{p}$ \\
\hline $\begin{array}{l}\text { Sosyal medya sayesinde rakip firmalar kolaylıkla takip } \\
\text { edilir ve değişikliklere uyum sağlanır. }\end{array}$ & $\begin{array}{l}\text { Evet } \\
\text { Hayır }\end{array}$ & $\begin{array}{c}7 \\
20\end{array}$ & $\begin{array}{l}4,85 \\
4,25\end{array}$ & $\begin{array}{l}, 377 \\
, 966\end{array}$ & 1,6 & , 122 \\
\hline $\begin{array}{l}\text { Sosyal medya sayesinde gelecek zamanda pazarlama için } \\
\text { kullanılacak olan müşteri bilgileri elde edilmektedir. }\end{array}$ & $\begin{array}{l}\text { Evet } \\
\text { Hayır }\end{array}$ & $\begin{array}{c}7 \\
20\end{array}$ & $\begin{array}{c}4,42 \\
4\end{array}$ & $\begin{array}{c}, 53 \\
1,02\end{array}$ & 1,04 & ,305 \\
\hline $\begin{array}{l}\text { Sosyal medya uluslararası pazarlama ve satış kolaylığı } \\
\text { sağlamaktadır. }\end{array}$ & $\begin{array}{l}\text { Evet } \\
\text { Hayir }\end{array}$ & $\begin{array}{c}7 \\
20\end{array}$ & $\begin{array}{l}4,57 \\
4,15\end{array}$ & $\begin{array}{l}, 53 \\
, 74\end{array}$ & 1,37 & , 183 \\
\hline Sosyal medya işletmede işgücü maliyetini azaltmaktadır. & $\begin{array}{l}\text { Evet } \\
\text { Hayir }\end{array}$ & $\begin{array}{c}7 \\
20\end{array}$ & $\begin{array}{c}3,42 \\
4,1\end{array}$ & $\begin{array}{l}1,71 \\
1,02\end{array}$ &,- 97 & ,36 \\
\hline $\begin{array}{l}\text { Sosyal medya sayesinde ürünlerin ve şirketin tanıtımı } \\
\text { kolaylıkla yapılmaktadır. }\end{array}$ & $\begin{array}{l}\text { Evet } \\
\text { Hayir }\end{array}$ & $\begin{array}{c}7 \\
20\end{array}$ & $\begin{array}{l}4,57 \\
4,15\end{array}$ & $\begin{array}{l}, 53 \\
, 97\end{array}$ & ,693 & ,495 \\
\hline $\begin{array}{l}\text { Sosyal medya satış sürecini ve hizmet sunumunu } \\
\text { standartlaştırmaktadır. }\end{array}$ & $\begin{array}{l}\text { Evet } \\
\text { Hayir }\end{array}$ & $\begin{array}{c}7 \\
20\end{array}$ & $\begin{array}{l}3 \\
3,35\end{array}$ & $\begin{array}{l}1,41 \\
1,18\end{array}$ &,- 64 &, 527 \\
\hline $\begin{array}{l}\text { Sosyal medya da ürünleri etkili şekilde pazarlamak } \\
\text { zordur. }\end{array}$ & $\begin{array}{l}\text { Evet } \\
\text { Hayir }\end{array}$ & $\begin{array}{c}7 \\
20\end{array}$ & $\begin{array}{c}2,57 \\
1,9\end{array}$ & $\begin{array}{l}1,81 \\
, 96\end{array}$ & ,934 & ,38 \\
\hline Tedarikçiler ve tüketiciler e-ticaret için yetersizdirler. & $\begin{array}{l}\text { Evet } \\
\text { Hayir }\end{array}$ & $\begin{array}{c}7 \\
20\end{array}$ & $\begin{array}{l}2,57 \\
2,45\end{array}$ & $\begin{array}{l}1,51 \\
1,14\end{array}$ & , 194 &, 851 \\
\hline $\begin{array}{l}\text { Şirkette sosyal medya için teknik uzmanlik eksiğimiz } \\
\text { mevcuttur. }\end{array}$ & $\begin{array}{l}\text { Evet } \\
\text { Hayir }\end{array}$ & $\begin{array}{c}7 \\
20\end{array}$ & $\begin{array}{c}3 \\
3,2\end{array}$ & $\begin{array}{l}1,91 \\
1,39\end{array}$ &,- 29 & ,77 \\
\hline $\begin{array}{l}\text { Sosyal medya kullanımının başlangıcında yüksek } \\
\text { maliyetler gereklidir. }\end{array}$ & $\begin{array}{l}\text { Evet } \\
\text { Hayır }\end{array}$ & $\begin{array}{c}7 \\
20\end{array}$ & $\begin{array}{c}2,42 \\
2,2\end{array}$ & $\begin{array}{l}1,61 \\
1,15\end{array}$ & ,344 & ,739 \\
\hline $\begin{array}{l}\text { Sosyal medya kullanımı stratejileri ile ilgili işletmelere } \\
\text { tavsiye eksikliği yer almaktadır. }\end{array}$ & $\begin{array}{l}\text { Evet } \\
\text { Hayir }\end{array}$ & $\begin{array}{c}7 \\
20\end{array}$ & $\begin{array}{l}3,28 \\
3,45\end{array}$ & $\begin{array}{l}1,79 \\
1,14\end{array}$ &,- 28 & ,781 \\
\hline $\begin{array}{l}\text { Sosyal medya önümüzde ki } 5-7 \text { yıl içerisinde turizm } \\
\text { sektörünün iş yapma şeklini değiştirecektir. }\end{array}$ & $\begin{array}{l}\text { Evet } \\
\text { Hayir }\end{array}$ & $\begin{array}{c}7 \\
20\end{array}$ & $\begin{array}{c}3,71 \\
4,1\end{array}$ & $\begin{array}{c}, 75 \\
1,11\end{array}$ &,- 84 & ,408 \\
\hline
\end{tabular}

* Veriler \%95 güven düzeyinde istatistiksel olarak anlamlıdır.

Yukarıda Tablo 9'a göre; eğitim alan kullanıcının $(x=5)$ eğitim almayan kullanıcıya göre $(x=4,3)$ sosyal medya kullanımı oldukça esnek ve kolaydır. Sosyal medya sayesinde ürünlerin pazarlanmasının kolay olma durumunda, eğitim alan katılımcı ile almayan katılımcı arasında anlamlı farklılık bulunmaktadır. Eğitim alan katılımcılar $(x=5)$ eğitim almayan katılımcılara $(x=3,95)$ göre sosyal medya sayesinde ürünlerin oldukça kolay pazarlanabildiğini belirtmektedirler.

Araştırma kapsamında incelen bir diğer araştırma alt sorusu "3: İşletmenin sosyal medya araçlarında pazarlama odaklı harcadıkları süre ile sosyal medya pazarlamasına ilişkin tutumları arasında anlamlı bir farklılık var mıdır?" sorusu ANOVA testi ile ölçülmüştür. Analiz sonuçları Tablo 10’da yer almaktadır. Analiz sonuçlarına göre $\mathrm{p}<0.05$ olduğundan istatistiksel olarak anlamlı bir farklılı̆̆a rastlanmaktadır. 
Tablo 10. İşletmelerin Sosyal Medyada Harcadıkları Sürelere Göre Sosyal Medya Pazarlamasına Yönelik Tutumlarının T-testi Sonuçları

\begin{tabular}{|c|c|c|c|c|c|c|}
\hline Yargilar & Harcanan Süre & $\mathbf{n}$ & $\mathbf{x}$ & s.s. & $\mathbf{F}$ & $\mathbf{p}$ \\
\hline \multirow{4}{*}{ Sosyal medya kullanımı oldukça esnek ve rahattır. } & 1 Saatten az & 4 & 4,75 & 0,50 & \multirow{4}{*}{1,52} & \multirow{4}{*}{0,23} \\
\hline & 1-5 Saat & 12 & 4,08 & 1,16 & & \\
\hline & 6-10 Saat & 5 & 4,80 & 0,44 & & \\
\hline & 11 Saatten Fazla & 6 & 4,83 & 0,40 & & \\
\hline \multirow{4}{*}{$\begin{array}{l}\text { Sosyal medya sayesinde müşterilere kolaylıkla } \\
\text { erişim sağlanmaktadır. }\end{array}$} & 1 Saatten az & 4 & 4,5 & 1,00 & \multirow{4}{*}{0,89} & \multirow{4}{*}{0,46} \\
\hline & 1-5 Saat & 12 & 4,25 & 1,13 & & \\
\hline & 6-10 Saat & 5 & 5,00 & 0,00 & & \\
\hline & 11 Saatten Fazla & 6 & 4,66 & 0,51 & & \\
\hline \multirow{4}{*}{$\begin{array}{l}\text { Sosyal medya sayesinde pazarlama maliyetleri } \\
\text { azaltmaktadır. }\end{array}$} & 1 Saatten az & 4 & 4,00 & 1,41 & \multirow{4}{*}{0,03} & \multirow{4}{*}{0,99} \\
\hline & 1-5 Saat & 12 & 4,00 & 1,04 & & \\
\hline & 6-10 Saat & 5 & 4,20 & 1,78 & & \\
\hline & 11 Saatten Fazla & 6 & 4,00 & 0,63 & & \\
\hline \multirow{4}{*}{$\begin{array}{l}\text { Sosyal medya sayesinde müşteriler ile etkileşim } \\
\text { artışı sağlanmaktadır. }\end{array}$} & 1 Saatten az & 4 & 4,5 & 0,57 & \multirow{4}{*}{1,16} & \multirow{4}{*}{0,34} \\
\hline & 1-5 Saat & 12 & 4,16 & 1,19 & & \\
\hline & 6-10 Saat & 5 & 5,00 & 0,00 & & \\
\hline & 11 Saatten Fazla & 6 & 4,66 & 0,51 & & \\
\hline \multirow{4}{*}{$\begin{array}{l}\text { Sosyal medya sayesinde müşteri portföyünü } \\
\text { hedeflemek ve tanımlamak daha kolaydır. }\end{array}$} & 1 Saatten az & 4 & 4,5 & 0,57 & \multirow{4}{*}{0,44} & \multirow{4}{*}{0,72} \\
\hline & 1-5 Saat & 12 & 4,08 & 1,16 & & \\
\hline & 6-10 Saat & 5 & 4,60 & 0,54 & & \\
\hline & 11 Saatten Fazla & 6 & 4,33 & 0,81 & & \\
\hline \multirow{4}{*}{$\begin{array}{l}\text { Sosyal medyada iletişim esnasında insan teması ve } \\
\text { güven eksikliği hissedilmektedir. }\end{array}$} & 1 Saatten az & 4 & 4,00 & 1,41 & \multirow{4}{*}{0,76} & \multirow{4}{*}{$0,52 *$} \\
\hline & 1-5 Saat & 12 & 2,91 & 1,31 & & \\
\hline & 6-10 Saat & 5 & 2,80 & 1,64 & & \\
\hline & 11 Saatten Fazla & 6 & 3,0 & 1,09 & & \\
\hline \multirow{4}{*}{$\begin{array}{l}\text { Sosyal medya } \\
\text { küreselleşmektedir } \\
\text { oluşturmaktadır. }\end{array}$} & 1 Saatten az & 4 & 4,50 & 0,57 & \multirow{4}{*}{0,51} & \multirow{4}{*}{0,67} \\
\hline & 1-5 Saat & 12 & 3,75 & 1,13 & & \\
\hline & 6-10 Saat & 5 & 4,20 & 1,78 & & \\
\hline & 11 Saatten Fazla & 6 & 4,19 & 0,75 & & \\
\hline \multirow{4}{*}{$\begin{array}{l}\text { Sosyal medyada yüz yüze satış esnasında sunulan } \\
\text { fırsatların eksikliği hissedilmektedir. }\end{array}$} & 1 Saatten az & 4 & 4,5 & 1,00 & \multirow{4}{*}{2,42} & \multirow{4}{*}{0,92} \\
\hline & 1-5 Saat & 12 & 2,75 & 1,28 & & \\
\hline & 6-10 Saat & 5 & 3,2 & 0,83 & & \\
\hline & 11 Saatten Fazla & 6 & 3,33 & 1,03 & & \\
\hline \multirow{3}{*}{$\begin{array}{l}\text { Sosyal medya da güvenlik sorunları yer } \\
\text { almaktadır. }\end{array}$} & 1 Saatten az & 4 & 4,75 & 0,50 & \multirow{3}{*}{2,76} & \multirow{3}{*}{0,52} \\
\hline & 1-5 Saat & 12 & 2,75 & 1,35 & & \\
\hline & 6-10 Saat & 5 & 2,80 & 1,30 & & \\
\hline
\end{tabular}




\begin{tabular}{|c|c|c|c|c|c|c|}
\hline Yargilar & Harcanan Süre & $\mathbf{n}$ & $\mathbf{x}$ & s.s. & $\mathbf{F}$ & p \\
\hline & 11 Saatten Fazla & 6 & 2,83 & 1,32 & & \\
\hline \multirow{4}{*}{$\begin{array}{l}\text { Sosyal medyada kişiye özel ürünler yerine } \\
\text { standart ürünler satılmaktadır. }\end{array}$} & 1 Saatten az & 4 & 3,00 & 1,41 & \multirow{4}{*}{0,55} & \multirow{4}{*}{0,64} \\
\hline & 1-5 Saat & 12 & 2,33 & 1,15 & & \\
\hline & 6-10 Saat & 5 & 2,00 & 1,41 & & \\
\hline & 11 Saatten Fazla & 6 & 2,00 & 1,54 & & \\
\hline \multirow{4}{*}{$\begin{array}{l}\text { Sosyal medya potansiyel müşterilerin şirkete karşı } \\
\text { yabancılaşmasına neden olmaktadır. }\end{array}$} & 1 Saatten az & 4 & 1,75 & 1,5 & \multirow{4}{*}{0,36} & \multirow{4}{*}{0,78} \\
\hline & 1-5 Saat & 12 & 1,83 & 1,11 & & \\
\hline & 6-10 Saat & 5 & 1,4 & 0,54 & & \\
\hline & 11 Saatten Fazla & 6 & 2,16 & 1,60 & & \\
\hline \multirow{4}{*}{$\begin{array}{l}\text { Sosyal medyada şirketin ürünlerini etkin şekilde } \\
\text { pazarlamak oldukça zordur. }\end{array}$} & 1 Saatten az & 4 & 2,00 & 2,00 & \multirow{4}{*}{0,79} & \multirow{4}{*}{0,50} \\
\hline & 1-5 Saat & 12 & 2,00 & 1,20 & & \\
\hline & 6-10 Saat & 5 & 1,40 & 0,54 & & \\
\hline & 11 Saatten Fazla & 6 & 2,66 & 1,63 & & \\
\hline \multirow{4}{*}{$\begin{array}{l}\text { Sosyal medyada müşterilerin ve satışların } \\
\text { kayıtlarını güncel tutmak oldukça zordur. }\end{array}$} & 1 Saatten az & 4 & 2,25 & 1,50 & \multirow{4}{*}{0,10} & \multirow{4}{*}{0,95} \\
\hline & 1-5 Saat & 12 & 1,91 & 1,08 & & \\
\hline & 6-10 Saat & 5 & 2,20 & 1,09 & & \\
\hline & 11 Saatten Fazla & 6 & 2,0 & 1,54 & & \\
\hline \multirow{4}{*}{$\begin{array}{l}\text { Sosyal medya sayesinde seyahat ürünleri } \\
\text { kolaylıkla pazarlanabilmektedir. }\end{array}$} & 1 Saatten az & 4 & 3,75 & 0,95 & \multirow{4}{*}{1,31} & \multirow{4}{*}{0,29} \\
\hline & 1-5 Saat & 12 & 4,00 & 1,12 & & \\
\hline & 6-10 Saat & 5 & 4,80 & 0,44 & & \\
\hline & 11 Saatten Fazla & 6 & 4,50 & 0,83 & & \\
\hline \multirow{4}{*}{$\begin{array}{l}\text { Sosyal medya sayesinde müşterilere birden fazla } \\
\text { seyahat hizmetleri sunulmaktadır. }\end{array}$} & 1 Saatten az & 4 & 4,25 & 0,50 & \multirow{4}{*}{1,25} & \multirow{4}{*}{0,31} \\
\hline & 1-5 Saat & 12 & 4,25 & 1,21 & & \\
\hline & 6-10 Saat & 5 & 5,00 & 0,00 & & \\
\hline & 11 Saatten Fazla & 6 & 4,83 & 0,40 & & \\
\hline \multirow{4}{*}{$\begin{array}{l}\text { Sosyal medya sayesinde rakip firmalar kolaylıkla } \\
\text { takip edilir ve değişikliklere uyum sağlanır. }\end{array}$} & 1 Saatten az & 4 & 4,75 & 0,50 & \multirow{4}{*}{0,63} & \multirow{4}{*}{0,60} \\
\hline & 1-5 Saat & 12 & 4,16 & 1,19 & & \\
\hline & 6-10 Saat & 5 & 4,40 & 0,54 & & \\
\hline & 11 Saatten Fazla & 6 & 4,66 & 0,51 & & \\
\hline \multirow{4}{*}{$\begin{array}{l}\text { Sosyal medya sayesinde gelecek zamanda } \\
\text { pazarlama için kullanılacak olan müşteri bilgileri } \\
\text { elde edilmektedir. }\end{array}$} & 1 Saatten az & 4 & 4,00 & 0,00 & \multirow{4}{*}{0,14} & \multirow{4}{*}{0,93} \\
\hline & 1-5 Saat & 12 & 4,08 & 1,16 & & \\
\hline & 6-10 Saat & 5 & 4,00 & 1,22 & & \\
\hline & 11 Saatten Fazla & 6 & 4,33 & 0,51 & & \\
\hline \multirow{4}{*}{$\begin{array}{l}\text { Sosyal medya uluslararası pazarlama ve satış } \\
\text { kolaylığı sağlamaktadır. }\end{array}$} & 1 Saatten az & 4 & 4,25 & 0,50 & \multirow{4}{*}{0,13} & \multirow{4}{*}{0,93} \\
\hline & 1-5 Saat & 12 & 4,16 & 0,93 & & \\
\hline & 6-10 Saat & 5 & 4,40 & 0,54 & & \\
\hline & 11 Saatten Fazla & 6 & 4,33 & 0,51 & & \\
\hline
\end{tabular}


Rize İli Seyahat Acentalarının Sosyal Medya Pazarlamasına Yönelik Algı ve Tutumları

\begin{tabular}{|c|c|c|c|c|c|c|}
\hline Yargılar & Harcanan Süre & $\mathbf{n}$ & $\mathbf{x}$ & s.s. & $\mathbf{F}$ & $\mathbf{p}$ \\
\hline \multirow{4}{*}{$\begin{array}{l}\text { Sosyal medya işletmede işgücü maliyetini } \\
\text { azaltmaktadır. }\end{array}$} & 1 Saatten az & 4 & 3,50 & 1,00 & \multirow{4}{*}{1,73} & \multirow{4}{*}{0,18} \\
\hline & 1-5 Saat & 12 & 3,66 & 1,30 & & \\
\hline & 6-10 Saat & 5 & 5,00 & 0,00 & & \\
\hline & 11 Saatten Fazla & 6 & 3,83 & 1,47 & & \\
\hline \multirow{4}{*}{$\begin{array}{l}\text { Sosyal medya sayesinde ürünlerin ve şirketin } \\
\text { tanıtımı kolaylıkla yapılmaktadır. }\end{array}$} & 1 Saatten az & 4 & 4,25 & 0,50 & \multirow{4}{*}{0,64} & \multirow{4}{*}{0,59} \\
\hline & 1-5 Saat & 12 & 4,16 & 1,19 & & \\
\hline & 6-10 Saat & 5 & 4,80 & 0,44 & & \\
\hline & 11 Saatten Fazla & 6 & 4,5 & 0,54 & & \\
\hline \multirow{4}{*}{$\begin{array}{l}\text { Sosyal medya satış sürecini ve hizmet sunumunu } \\
\text { standartlaştırmaktadır. }\end{array}$} & 1 Saatten az & 4 & 3,50 & 0,57 & \multirow{4}{*}{0,53} & \multirow{4}{*}{0,66} \\
\hline & 1-5 Saat & 12 & 3,00 & 1,27 & & \\
\hline & 6-10 Saat & 5 & 3,80 & 1,64 & & \\
\hline & 11 Saatten Fazla & 6 & 3,16 & 1,16 & & \\
\hline \multirow{4}{*}{$\begin{array}{l}\text { Sosyal medya da ürünleri etkili şekilde } \\
\text { pazarlamak zordur. }\end{array}$} & 1 Saatten az & 4 & 2,25 & 1,89 & \multirow{4}{*}{0,19} & \multirow{4}{*}{0,90} \\
\hline & 1-5 Saat & 12 & 2,00 & 1,12 & & \\
\hline & 6-10 Saat & 5 & 1,80 & 0,83 & & \\
\hline & 11 Saatten Fazla & 6 & 2,33 & 1,50 & & \\
\hline \multirow{4}{*}{$\begin{array}{l}\text { Tedarikçiler ve tüketiciler e-ticaret için } \\
\text { yetersizdirler. }\end{array}$} & 1 Saatten az & 4 & 3,00 & 1,41 & \multirow{4}{*}{0,70} & \multirow{4}{*}{0,56} \\
\hline & 1-5 Saat & 12 & 2,66 & 1,15 & & \\
\hline & 6-10 Saat & 5 & 2,00 & 0,70 & & \\
\hline & 11 Saatten Fazla & 6 & 2,16 & 1,60 & & \\
\hline \multirow{4}{*}{$\begin{array}{l}\text { Şirkette sosyal medya için teknik uzmanlık } \\
\text { eksiğimiz mevcuttur. }\end{array}$} & 1 Saatten az & 4 & 4,00 & 0,00 & \multirow{4}{*}{1,53} & \multirow{4}{*}{0,23} \\
\hline & $1-5$ Saat & 12 & 3,33 & 1,49 & & \\
\hline & 6-10 Saat & 5 & 2,00 & 1,41 & & \\
\hline & 11 Saatten Fazla & 6 & 3,16 & 1,83 & & \\
\hline \multirow{4}{*}{$\begin{array}{l}\text { Sosyal medya kullanımının başlangıcında yüksek } \\
\text { maliyetler gereklidir. }\end{array}$} & 1 Saatten az & 4 & 2,5 & 1,00 & \multirow{4}{*}{0,56} & \multirow{4}{*}{0,64} \\
\hline & $1-5$ Saat & 12 & 2,33 & 1,30 & & \\
\hline & 6-10 Saat & 5 & 1,60 & 0,89 & & \\
\hline & 11 Saatten Fazla & 6 & 2,5 & 1,64 & & \\
\hline \multirow{4}{*}{$\begin{array}{l}\text { Sosyal medya kullanımı stratejileri ile ilgili } \\
\text { işletmelere tavsiye eksikliği yer almaktadır. }\end{array}$} & 1 Saatten az & 4 & 3,50 & 1,29 & \multirow{4}{*}{1,82} & \multirow{4}{*}{0,17} \\
\hline & 1-5 Saat & 12 & 3,91 & 0,90 & & \\
\hline & 6-10 Saat & 5 & 2,40 & 1,14 & & \\
\hline & 11 Saatten Fazla & 6 & 3,16 & 1,83 & & \\
\hline \multirow{4}{*}{$\begin{array}{l}\text { Sosyal medya önümüzde ki } 5-7 \text { yıl içerisinde } \\
\text { turizm sektörünün iş yapma şeklini değiştirecektir. }\end{array}$} & 1 Saatten az & 4 & 4,25 & 0,95 & \multirow{4}{*}{0,21} & \multirow{4}{*}{0,88} \\
\hline & 1-5 Saat & 12 & 3,83 & 1,11 & & \\
\hline & 6-10 Saat & 5 & 4,00 & 1,41 & & \\
\hline & 11 Saatten Fazla & 6 & 4,16 & 0,75 & & \\
\hline
\end{tabular}

* Veriler \%95 güven düzeyinde istatistiksel olarak anlamlıdır. 
Tablo 10'da yer alan analiz sonuçlarına göre sosyal medyanın güvenlik sorunu oluşturduğu düşüncesi sosyal medya pazarlaması için 1 saatten az harcanan süren ile daha fazla harcanan süre arasında anlamlı bir fark vardır. Sosyal medya pazarlaması için 1 saatten daha az harcayan işletmeler $(\mathrm{p}=0,52)$ daha fazla harcayan işletmelere göre sosyal medyanın güvenlik sorunu oluşturduğunu belirtmektedir.

Araştırma kapsamında geliştirilen dördüncü araştırma alt sorusu olan "4: İşletmenin sosyal medya kullanım süresi ile sosyal medya pazarlamasına ilişkin tutumları arasında anlamlı farklılık var mıdır?” sorusu ANOVA testi ile incelenmiştir. Analiz sonucuna göre $p>0.05$ olduğundan dolayı herhangi bir anlamlı farklılığa rastlanmamıştır.

Araştırma kapsamında incelen son araştırma alt sorusu olan "5: Seyahat acentalarında çalışan personellerin işyerindeki görevi ile sosyal medya pazarlamasına ilişkin tutumları arasında anlamlı bir farklılık var mıdır?" sorusu ANOVA testi ile analiz edilmiştir. Analize yönelik sonuçlar Tablo 11'de verilmiştir. Analiz sonucunda $\mathrm{p}<0.05$ olduğundan istatistiksel olarak anlamlı bir farklılık ortaya çıkmaktadır.

Tablo 11: İşletme Çalışanlarının İşletmedeki Görevlerine Göre Sosyal Medya Pazarlamasına Yönelik Tutumlarının T-testi sonuçları

\begin{tabular}{|c|c|c|c|c|c|c|}
\hline Yargilar & İşletmedeki Görev & $\mathbf{n}$ & $\mathbf{x}$ & S.s. & $\mathbf{F}$ & p \\
\hline \multirow{5}{*}{$\begin{array}{l}\text { Sosyal medya kullanımı oldukça esnek ve } \\
\text { rahattır. }\end{array}$} & İşletme Sahibi & 15 & 4,33 & 1,11 & \multirow{5}{*}{0,40} & \multirow{5}{*}{0,80} \\
\hline & Genel Müdür & 2 & 4,50 & 0,70 & & \\
\hline & $\begin{array}{l}\text { Hem İşletme Müdürü } \\
\text { Hem Genel Müdür }\end{array}$ & 6 & 4,50 & 0,54 & & \\
\hline & Operasyon Müdürü & 2 & 5,0 & 0,0 & & \\
\hline & Rezervasyon Sorumlusu & 2 & 5,0 & 0,0 & & \\
\hline \multirow{5}{*}{$\begin{array}{l}\text { Sosyal medya sayesinde müşterilere } \\
\text { kolaylıkla erişim sağlanmaktadır. }\end{array}$} & İşletme Sahibi & 15 & 4,46 & 1,12 & \multirow{5}{*}{0,33} & \multirow{5}{*}{0,85} \\
\hline & Genel Müdür & 2 & 4,50 & 0,70 & & \\
\hline & $\begin{array}{l}\text { Hem İşletme Müdürü } \\
\text { Hem Genel Müdür }\end{array}$ & 6 & 4,66 & 0,51 & & \\
\hline & Operasyon Müdürü & 2 & 5,0 & 0,0 & & \\
\hline & Rezervasyon Sorumlusu & 2 & 5,0 & 0,0 & & \\
\hline \multirow{5}{*}{$\begin{array}{l}\text { Sosyal medya sayesinde pazarlama } \\
\text { maliyetleri azaltmaktadir. }\end{array}$} & İşletme Sahibi & 15 & 3,86 & 1,40 & \multirow{5}{*}{0,24} & \multirow{5}{*}{0,91} \\
\hline & Genel Müdür & 2 & 4,50 & 0,70 & & \\
\hline & $\begin{array}{l}\text { Hem İşletme Müdürü } \\
\text { Hem Genel Müdür }\end{array}$ & 6 & 4,16 & 0,75 & & \\
\hline & Operasyon Müdürü & 2 & 4,50 & 0,70 & & \\
\hline & Rezervasyon Sorumlusu & 2 & 4,00 & 0,00 & & \\
\hline \multirow{5}{*}{$\begin{array}{l}\text { Sosyal medya sayesinde müşteriler ile } \\
\text { etkileşim artışı sağlanmaktadır. }\end{array}$} & İşletme Sahibi & 15 & 4,40 & 1,12 & \multirow{5}{*}{0,37} & \multirow{5}{*}{0,82} \\
\hline & Genel Müdür & 2 & 4,50 & 0,70 & & \\
\hline & $\begin{array}{l}\text { Hem İşletme Müdürü } \\
\text { Hem Genel Müdür }\end{array}$ & 6 & 4,66 & 0,51 & & \\
\hline & Operasyon Müdürü & 2 & 5,0 & 0,00 & & \\
\hline & Rezervasyon Sorumlusu & 2 & 4,0 & 0,00 & & \\
\hline sayesinde & İşletme Sahibi & 15 & 4,20 & 1,08 & 0,47 & 0,75 \\
\hline
\end{tabular}


Rize İli Seyahat Acentalarının Sosyal Medya Pazarlamasına Yönelik Algı ve Tutumları

\begin{tabular}{|c|c|c|c|c|c|c|}
\hline Yargılar & İşletmedeki Görev & $\mathbf{n}$ & $\mathbf{x}$ & S.S. & $\mathbf{F}$ & $\mathbf{p}$ \\
\hline \multirow{4}{*}{$\begin{array}{l}\text { portföyünü hedeflemek ve tanımlamak } \\
\text { daha kolaydır. }\end{array}$} & Genel Müdür & 2 & 4,0 & 1,41 & & \\
\hline & $\begin{array}{l}\text { Hem İşletme Müdürü } \\
\text { Hem Genel Müdür }\end{array}$ & 6 & 4,50 & 0,54 & & \\
\hline & Operasyon Müdürü & 2 & 5,0 & 0,00 & & \\
\hline & Rezervasyon Sorumlusu & 2 & 4,0 & 0,00 & & \\
\hline \multirow{5}{*}{$\begin{array}{l}\text { Sosyal medyada iletişim esnasında insan } \\
\text { teması ve güven eksikliği } \\
\text { hissedilmektedir. }\end{array}$} & İşletme Sahibi & 15 & 2,80 & 1,47 & \multirow{5}{*}{0,76} & \multirow{5}{*}{0,55} \\
\hline & Genel Müdür & 2 & 3,50 & 0,70 & & \\
\hline & $\begin{array}{l}\text { Hem İşletme Müdürü } \\
\text { Hem Genel Müdür }\end{array}$ & 6 & 3,83 & 0,98 & & \\
\hline & Operasyon Müdürü & 2 & 2,50 & 2,12 & & \\
\hline & Rezervasyon Sorumlusu & 2 & 3,00 & 0,00 & & \\
\hline \multirow{5}{*}{ 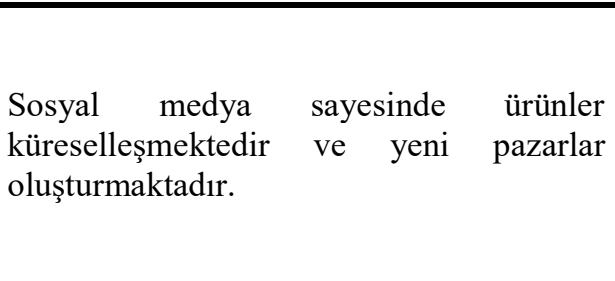 } & İşletme Sahibi & 15 & 3,93 & 1,38 & \multirow{5}{*}{0,36} & \multirow{5}{*}{0,83} \\
\hline & Genel Müdür & 2 & 3,50 & 0,70 & & \\
\hline & $\begin{array}{l}\text { Hem İşletme Müdürü } \\
\text { Hem Genel Müdür }\end{array}$ & 6 & 4,50 & 0,54 & & \\
\hline & Operasyon Müdürü & 2 & 4,00 & 1,41 & & \\
\hline & Rezervasyon Sorumlusu & 2 & 4,00 & 0,00 & & \\
\hline \multirow{5}{*}{$\begin{array}{l}\text { Sosyal medyada yüz yüze satış esnasında } \\
\text { sunulan firsatların } \\
\text { hissedilmektedir. }\end{array}$} & İşletme Sahibi & 15 & 2,93 & 1,33 & \multirow{5}{*}{1,41} & \multirow{5}{*}{0,26} \\
\hline & Genel Müdür & 2 & 3,50 & 0,70 & & \\
\hline & $\begin{array}{l}\text { Hem İşletme Müdürü } \\
\text { Hem Genel Müdür }\end{array}$ & 6 & 4,16 & 0,40 & & \\
\hline & Operasyon Müdürü & 2 & 2,50 & 2,12 & & \\
\hline & Rezervasyon Sorumlusu & 2 & 3,00 & 0,00 & & \\
\hline \multirow{5}{*}{$\begin{array}{l}\text { Sosyal medya da güvenlik sorunları yer } \\
\text { almaktadır. }\end{array}$} & İşletme Sahibi & 15 & 2,86 & 1,50 & \multirow{5}{*}{0,45} & \multirow{5}{*}{0,77} \\
\hline & Genel Müdür & 2 & 3,50 & 0,70 & & \\
\hline & $\begin{array}{l}\text { Hem İşletme Müdürü } \\
\text { Hem Genel Müdür }\end{array}$ & 6 & 3,66 & 1,36 & & \\
\hline & Operasyon Müdürü & 2 & 2,50 & 2,12 & & \\
\hline & Rezervasyon Sorumlusu & 2 & 3,00 & 0,00 & & \\
\hline \multirow{5}{*}{$\begin{array}{l}\text { Sosyal medyada kişiye özel ürünler yerine } \\
\text { standart ürünler satılmaktadır. }\end{array}$} & İşletme Sahibi & 15 & 2,33 & 1,44 & \multirow{5}{*}{1,59} & \multirow{5}{*}{0,21} \\
\hline & Genel Müdür & 2 & 2,50 & 0,70 & & \\
\hline & $\begin{array}{l}\text { Hem İşletme Müdürü } \\
\text { Hem Genel Müdür }\end{array}$ & 6 & 3,00 & 0,89 & & \\
\hline & Operasyon Müdürü & 2 & 1,00 & 0,00 & & \\
\hline & Rezervasyon Sorumlusu & 2 & 1,00 & 0,00 & & \\
\hline \multirow{5}{*}{$\begin{array}{l}\text { Sosyal medya potansiyel müşterilerin } \\
\text { şirkete karşı yabancılaşmasına neden } \\
\text { olmaktadır. }\end{array}$} & İşletme Sahibi & 15 & 1,80 & 1,26 & \multirow{5}{*}{0,75} & \multirow{5}{*}{0,56} \\
\hline & Genel Müdür & 2 & 2,00 & 0,00 & & \\
\hline & $\begin{array}{l}\text { Hem İşletme Müdürü } \\
\text { Hem Genel Müdür }\end{array}$ & 6 & 2,33 & 1,36 & & \\
\hline & Operasyon Müdürü & 2 & 1,00 & 0,00 & & \\
\hline & Rezervasyon Sorumlusu & 2 & 1,00 & 0,00 & & \\
\hline \multirow{5}{*}{$\begin{array}{l}\text { Sosyal medyada şirketin ürünlerini etkin } \\
\text { şekilde pazarlamak oldukça zordur. }\end{array}$} & İşletme Sahibi & 15 & 2,26 & 1,48 & \multirow{5}{*}{0,83} & \multirow{5}{*}{0,51} \\
\hline & Genel Müdür & 2 & 1,50 & 0,70 & & \\
\hline & $\begin{array}{l}\text { Hem İşletme Müdürü } \\
\text { Hem Genel Müdür }\end{array}$ & 6 & 2,33 & 1,36 & & \\
\hline & Operasyon Müdürü & 2 & 1,00 & 0,00 & & \\
\hline & Rezervasyon Sorumlusu & 2 & 1,00 & 0,00 & & \\
\hline
\end{tabular}




\begin{tabular}{|c|c|c|c|c|c|c|}
\hline Yargilar & İşletmedeki Görev & $\mathbf{n}$ & $\mathbf{x}$ & s.s. & $\mathbf{F}$ & $\mathbf{p}$ \\
\hline \multirow{5}{*}{$\begin{array}{l}\text { Sosyal medyada müşterilerin ve satışların } \\
\text { kayıtlarını güncel tutmak oldukça zordur. }\end{array}$} & İşletme Sahibi & 15 & 2,06 & 1,27 & \multirow{5}{*}{0,67} & \multirow{5}{*}{0,61} \\
\hline & Genel Müdür & 2 & 2,00 & 0,00 & & \\
\hline & $\begin{array}{l}\text { Hem İşletme Müdürü } \\
\text { Hem Genel Müdür }\end{array}$ & 6 & 2,50 & 1,37 & & \\
\hline & Operasyon Müdürü & 2 & 1,50 & 0,70 & & \\
\hline & Rezervasyon Sorumlusu & 2 & 1,00 & 0,00 & & \\
\hline \multirow{5}{*}{$\begin{array}{l}\text { Sosyal medya sayesinde seyahat ürünleri } \\
\text { kolaylıkla pazarlanabilmektedir. }\end{array}$} & İşletme Sahibi & 15 & 4,06 & 1,16 & \multirow{5}{*}{0,83} & \multirow{5}{*}{0,52} \\
\hline & Genel Müdür & 2 & 4,50 & 0,70 & & \\
\hline & $\begin{array}{l}\text { Hem İşletme Müdürü } \\
\text { Hem Genel Müdür }\end{array}$ & 6 & 4,00 & 0,63 & & \\
\hline & Operasyon Müdürü & 2 & 5,00 & 0,00 & & \\
\hline & Rezervasyon Sorumlusu & 2 & 5,00 & 0,00 & & \\
\hline \multirow{5}{*}{$\begin{array}{l}\text { Sosyal medya } \\
\text { birden fayesinde } \\
\text { sunulmaktadır. }\end{array}$} & İşletme Sahibi & 15 & 4,40 & 1,12 & \multirow{5}{*}{0,32} & \multirow{5}{*}{0,86} \\
\hline & Genel Müdür & 2 & 4,50 & 0,70 & & \\
\hline & $\begin{array}{l}\text { Hem İşletme Müdürü } \\
\text { Hem Genel Müdür }\end{array}$ & 6 & 4,50 & 0,54 & & \\
\hline & Operasyon Müdürü & 2 & 5,00 & 0,00 & & \\
\hline & Rezervasyon Sorumlusu & 2 & 5,00 & 0,00 & & \\
\hline \multirow{5}{*}{$\begin{array}{l}\text { Sosyal medya sayesinde rakip firmalar } \\
\text { kolaylıkla takip edilir ve değişikliklere } \\
\text { uyum sağlanır. }\end{array}$} & İşletme Sahibi & 15 & 4,33 & 1,11 & \multirow{5}{*}{0,54} & \multirow{5}{*}{0,70} \\
\hline & Genel Müdür & 2 & 4,50 & 0,70 & & \\
\hline & $\begin{array}{l}\text { Hem İşletme Müdürü } \\
\text { Hem Genel Müdür }\end{array}$ & 6 & 4,16 & 0,40 & & \\
\hline & Operasyon Müdürü & 2 & 5,00 & 0,00 & & \\
\hline & Rezervasyon Sorumlusu & 2 & 5,00 & 0,00 & & \\
\hline \multirow{5}{*}{$\begin{array}{l}\text { Sosyal medya sayesinde gelecek zamanda } \\
\text { pazarlama için kullanılacak olan müşteri } \\
\text { bilgileri elde edilmektedir. }\end{array}$} & İşletme Sahibi & 15 & 4,00 & 1,19 & \multirow{5}{*}{0,21} & \multirow{5}{*}{0,93} \\
\hline & Genel Müdür & 2 & 4,50 & 0,70 & & \\
\hline & $\begin{array}{l}\text { Hem İşletme Müdürü } \\
\text { Hem Genel Müdür }\end{array}$ & 6 & 4,16 & 0,40 & & \\
\hline & Operasyon Müdürü & 2 & 4,50 & 0,70 & & \\
\hline & Rezervasyon Sorumlusu & 2 & 4,00 & 0,00 & & \\
\hline \multirow{5}{*}{$\begin{array}{l}\text { Sosyal medya uluslararası pazarlama ve } \\
\text { satış kolaylığı sağlamaktadır. }\end{array}$} & İşletme Sahibi & 15 & 4,26 & 0,88 & \multirow{5}{*}{0,18} & \multirow{5}{*}{0,94} \\
\hline & Genel Müdür & 2 & 4,50 & 0,70 & & \\
\hline & $\begin{array}{l}\text { Hem İşletme Müdürü } \\
\text { Hem Genel Müdür }\end{array}$ & 6 & 4,16 & 0,40 & & \\
\hline & Operasyon Müdürü & 2 & 4,50 & 0,70 & & \\
\hline & Rezervasyon Sorumlusu & 2 & 4,0 & 0,00 & & \\
\hline \multirow{5}{*}{$\begin{array}{l}\text { Sosyal medya işletmede işgücü maliyetini } \\
\text { azaltmaktadır. }\end{array}$} & İşletme Sahibi & 15 & 4,26 & 1,09 & \multirow{5}{*}{4,34} & \multirow{5}{*}{$0,01^{*}$} \\
\hline & Genel Müdür & 2 & 4,00 & 1,41 & & \\
\hline & $\begin{array}{l}\text { Hem İşletme Müdürü } \\
\text { Hem Genel Müdür }\end{array}$ & 6 & 4,33 & 0,51 & & \\
\hline & Operasyon Müdürü & 2 & 2,00 & 1,41 & & \\
\hline & Rezervasyon Sorumlusu & 2 & 2,00 & 0,00 & & \\
\hline \multirow{4}{*}{$\begin{array}{l}\text { Sosyal medya sayesinde ürünlerin ve } \\
\text { şirketin tanıtımı kolaylıkla yapılmaktadır. }\end{array}$} & İşletme Sahibi & 15 & 4,33 & 1,11 & \multirow{4}{*}{0,32} & \multirow{4}{*}{0,85} \\
\hline & Genel Müdür & 2 & 4,50 & 0,70 & & \\
\hline & $\begin{array}{l}\text { Hem İşletme Müdürü } \\
\text { Hem Genel Müdür }\end{array}$ & 6 & 4,33 & 0,51 & & \\
\hline & Operasyon Müdürü & 2 & 5,00 & 0,00 & & \\
\hline
\end{tabular}


Rize İli Seyahat Acentalarının Sosyal Medya Pazarlamasına Yönelik Algı ve Tutumları

\begin{tabular}{|c|c|c|c|c|c|c|}
\hline Yargılar & İşletmedeki Görev & $\mathbf{n}$ & $\mathbf{x}$ & S.S. & $\mathbf{F}$ & $\mathbf{p}$ \\
\hline & Rezervasyon Sorumlusu & 2 & 4,00 & 0,00 & & \\
\hline \multirow{5}{*}{$\begin{array}{l}\text { Sosyal medya satış sürecini ve hizmet } \\
\text { sunumunu standartlaştırmaktadır. }\end{array}$} & İşletme Sahibi & 15 & 3,46 & 1,30 & \multirow{5}{*}{1,43} & \multirow{5}{*}{0,25} \\
\hline & Genel Müdür & 2 & 4,00 & 1,41 & & \\
\hline & $\begin{array}{l}\text { Hem İşletme Müdürü } \\
\text { Hem Genel Müdür }\end{array}$ & 6 & 3,33 & 0,81 & & \\
\hline & Operasyon Müdürü & 2 & 2,0 & 1,41 & & \\
\hline & Rezervasyon Sorumlusu & 2 & 2,0 & 0,00 & & \\
\hline \multirow{5}{*}{$\begin{array}{l}\text { Sosyal medya da ürünleri etkili şekilde } \\
\text { pazarlamak zordur. }\end{array}$} & İşletme Sahibi & 15 & 2,06 & 1,38 & \multirow{5}{*}{1,18} & \multirow{5}{*}{0,34} \\
\hline & Genel Müdür & 2 & 2,50 & 0,70 & & \\
\hline & $\begin{array}{l}\text { Hem İşletme Müdürü } \\
\text { Hem Genel Müdür }\end{array}$ & 6 & 2,66 & 1,03 & & \\
\hline & Operasyon Müdürü & 2 & 1,0 & 0,00 & & \\
\hline & Rezervasyon Sorumlusu & 2 & 1,0 & 0,00 & & \\
\hline \multirow{5}{*}{$\begin{array}{l}\text { Tedarikçiler ve tüketiciler e-ticaret için } \\
\text { yetersizdirler. }\end{array}$} & İşletme Sahibi & 15 & 2,26 & 1,27 & \multirow{5}{*}{1,65} & \multirow{5}{*}{0,19} \\
\hline & Genel Müdür & 2 & 3,0 & 1,41 & & \\
\hline & $\begin{array}{l}\text { Hem İşletme Müdürü } \\
\text { Hem Genel Müdür }\end{array}$ & 6 & 3,16 & 0,98 & & \\
\hline & Operasyon Müdürü & 2 & 3,0 & 0,00 & & \\
\hline & Rezervasyon Sorumlusu & 2 & 1,0 & 0,00 & & \\
\hline \multirow{5}{*}{$\begin{array}{l}\text { Şirkette sosyal medya için teknik } \\
\text { uzmanlık eksiğimiz mevcuttur. }\end{array}$} & İşletme Sahibi & 15 & 3,20 & 1,47 & \multirow{5}{*}{1,27} & \multirow{5}{*}{0,31} \\
\hline & Genel Müdür & 2 & 3,50 & 0,70 & & \\
\hline & $\begin{array}{l}\text { Hem İşletme Müdürü } \\
\text { Hem Genel Müdür } \\
\end{array}$ & 6 & 3,66 & 1,36 & & \\
\hline & Operasyon Müdürü & 2 & 3,00 & 2,82 & & \\
\hline & Rezervasyon Sorumlusu & 2 & 1,00 & 0,0 & & \\
\hline \multirow{5}{*}{$\begin{array}{l}\text { Sosyal medya kullanımının başlangıcında } \\
\text { yüksek maliyetler gereklidir. }\end{array}$} & İşletme Sahibi & 15 & 2,53 & 1,35 & \multirow{5}{*}{1,11} & \multirow{5}{*}{0,37} \\
\hline & Genel Müdür & 2 & 1,50 & 0,70 & & \\
\hline & $\begin{array}{l}\text { Hem İşletme Müdürü } \\
\text { Hem Genel Müdür }\end{array}$ & 6 & 2,50 & 1,22 & & \\
\hline & Operasyon Müdürü & 2 & 1,50 & 0,70 & & \\
\hline & Rezervasyon Sorumlusu & 2 & 1,00 & 0,00 & & \\
\hline \multirow{5}{*}{$\begin{array}{l}\text { Sosyal medya kullanımı stratejileri ile } \\
\text { ilgili işletmelere tavsiye eksikliği yer } \\
\text { almaktadır. }\end{array}$} & İşletme Sahibi & 15 & 3,73 & 1,16 & \multirow{5}{*}{3,26} & \multirow{5}{*}{$0,03 *$} \\
\hline & Genel Müdür & 2 & 3,50 & 0,70 & & \\
\hline & $\begin{array}{l}\text { Hem İşletme Müdürü } \\
\text { Hem Genel Müdür }\end{array}$ & 6 & 3,00 & 1,26 & & \\
\hline & Operasyon Müdürü & 2 & 4,50 & 0,70 & & \\
\hline & Rezervasyon Sorumlusu & 2 & 1,00 & 0,00 & & \\
\hline \multirow{5}{*}{$\begin{array}{l}\text { Sosyal medya önümüzde ki } 5-7 \text { y1l } \\
\text { içerisinde turizm sektörünün iş yapma } \\
\text { şeklini değiştirecektir. }\end{array}$} & İşletme Sahibi & 15 & 4,0 & 1,30 & \multirow{5}{*}{0,13} & \multirow{5}{*}{0,96} \\
\hline & Genel Müdür & 2 & 4,0 & 0,00 & & \\
\hline & $\begin{array}{l}\text { Hem İşletme Müdürü } \\
\text { Hem Genel Müdür }\end{array}$ & 6 & 4,16 & 0,75 & & \\
\hline & Operasyon Müdürü & 2 & 3,50 & 0,70 & & \\
\hline & Rezervasyon Sorumlusu & 2 & 4,0 & 0,00 & & \\
\hline
\end{tabular}

* Veriler \%95 güven düzeyinde istatistiksel olarak anlamlıdır.

Tablo 11'göre; işyeri sahibi olan katılımcılar $(x=4,26)$ sosyal medya pazarlamasının operasyon müdürü $(x=2,0)$ ve rezervasyon sorumlusuna $(x=2,0)$ göre iş gücü maliyetini 
azalttığını belirtmektedir. Sosyal medya kullanımı stratejileri ile ilgili işletmelerin tavsiye eksikliğinin olması ile işletmedeki görev arasında ANOVA testine göre anlamlı bir farklılık saptanmıştır. İşletme sahibi ile $(x=3,5)$ rezervasyon sorumlusu $(x=1,0)$ arasında ve operasyon müdürü $(\mathrm{x}=4,5)$ ile rezervasyon sorumlusu $(\mathrm{x}=1,0)$ arasında anlamlı bir farkl1lık mevcuttur.

\section{Çalışmanın Literatür Açısından Karşılaştırılması ve Değerlendirme}

Literatürde işletmelerin sosyal medya pazarlamasını kullanma yahut kullanmama amaçlarına ilişkin farklı sonuçlara ulaşılmıştır. İşletmeler tarafından sosyal medya pazarlamasının; ürünlerini pazarlamak, farklı rakiplere karşı rekabet avantajı elde etmek, tüketiciyi bilgilendirmek (Yeniçıktı, 2016; Yılmazdoğan, 2014; Ozturan, 2004), marka bilinirliliğini artırmak, tüketici ile etkileşimi artırmak (Çelen ve Tuna, 2018; Jones vd., 2015; Yılmazdoğan, 2013; Civelek ve Dalgın, 2013; Baş, 2015; Buzlukçu, 2015; Yung, 1997; Park, 2012), pazarlama maliyetlerinin diğer yöntemlere göre ucuz olması, satışların ve karlılığın arttırılması (Karabulut, 2015), ürünlerin yurtdışı pazarında da tanıtılması (Kaşl1, 2006), tedarikçilerle işbirliği içerisinde olmak (Buhalis, 2002) gibi amaçlar için kullanıldığı ifade edilmektedir. Araştırmamızın sonucunda ise literatürde yer alan çalışmalarla benzer sonuçlara ulaşılmış olup, seyahat acentaları tarafından sosyal medya pazarlamasının; işletmelerin tüketiciye ulaştırmak istedikleri ürünlere ait fotoğraf ya da video paylaşımlarında bulunmak, işletmenin bilinirliliğini artırmak, tüketicilerle iletişime geçmek amacıyla kullanıldığı sonucuna ulaşılmıştır.

Literatürün değerlendirilmesi sonucunda, işletmeler tarafından sosyal medya pazarlamasının tercih edilmeme nedenleri arasında ise; profesyonel personelin istihdam edilmemiş olması, bilgi birikiminin olmaması, zamanın yetersiz olması, finansal kaynağın yetersiz olması, gerekli altyapı eksiklerinin olması, işletmelerin ihtiyaç duymaması, sosyal medyanın oluşturduğu güvenlik sorunu (Yılmazdoğan, 2014; Gülbahar ve Yildirim, 2015; Jones, 2014; Karabulut, 2015; Kaşl1, 2006; Vrana ve Zafiropoulos, 2006; Yung, 1997; Gümüş ve Kütahyalı, 2017; Jones vd., 2015) yer aldığ 1 tespit edilmiştir. Araştırmamızdan elde edilen sonuca göreyse; sosyal medya pazarlamasını kullanmayan işletmeler, sosyal medyanın güvenlik sorunu oluşturduğunu ve potansiyel müşterilere sosyal medya platformu ile ulaşılamayacağını belirtmektedirler.

Yılmazdoğan ve Özel (2014) tarafından yapılan çalışmada, sosyal medya pazarlamasına yönelik algı ve tutumda yaş faktörünün anlamlı farkl1lı̆̆a sahip olup, yaş arttıkça sosyal medya pazarlamasının yararlarına yönelik algıda azalmakta ve faydalı bulunmamaktadır. Buna ek olarak Yılmazdoğan (2013) yapmış olduğu çalışmada, çalışanların eğitim seviyesi arttıkça, sosyal medya pazarlamasına yönelik algı ve tutumda olumlu şekilde artış göstermektedir. 
Araştırmamızda ise; sosyal medya pazarlamasına yönelik algı ve tutum ile demografik faktörler arasında herhangi bir farklılığa rastlanmamıştır.

Buzlukçu (2005) ve Tekeli (2008) yapmış oldukları çalışmalar sonucunda işletme bünyesinde sosyal medya pazarlamasına ilişkin eğitim alan çalışan sayısının az olduğu sonucuna ulaşmışlardır. Araştırmamızla da benzer sonuca ulaşılmış ayrıca çoğu acenta sosyal medya pazarlaması ile ilgili herhangi bir eğitim almadıklarını ifade etmişlerdir.

\section{Sonuç}

Sosyal medya pazarlaması, işletmelere diğer pazarlama yöntemlerine göre daha düşük bütçelerle tanıtım ve markalaşma fırsatı sunarken; tüketiciyle yakından etkileşim konusunda önemli avantajlar sağlamaktadır. Ayrıca işletmelerin sosyal medyayı verimli şekilde kullanması, faaliyette bulundukları pazarda rekabet avantajı yakalamalarına da katkı sağlamaktadır.

Rize'de faaliyet gösteren seyahat acentalarının sosyal medya pazarlamasına yönelik alg1 ve tutumlarının incelendiği çalışma neticesinde, acentaların büyük çoğunluğunun sosyal medya pazarlamasına yöneldikleri tespit edilmiş, buradan yola çıkılarak seyahat acentelerinin sosyal medya pazarlamasına yönelik tutum ve algılarının olumlu olduğu sonucuna ulaşılmıştır. Acentalar, sosyal medya pazarlamasını farklı içerikler paylaşarak müşterinin dikkatini çekmek ve şirket ile ilgili video veya fotoğraf paylaşmak amacıyla kullanmaktadırlar. Sosyal medya pazarlamasını kullanmayan acentalar ise, sosyal medya pazarlamasını güvenilir bulmamakta ve müşterilerine sosyal medya aracılığı ile ulaşmanın mümkün olmadığını düşünmektedirler. Dolayısıyla bu acentaların sosyal medya pazarlamasına daha az vakit harcadıkları görülmektedir. Ayrıca sosyal medyanın kendileri için güvenlik sorunu oluşturduğunu da dile getirmektedirler. Gelişen dijital çağda devlet, işletme ve bireylerin göstermiş oldukları bu hassasiyete karşılık güvenlik sorununu en aza indirgemekte ve gerekli güvenlik tedbirlerini almaktadır. Haliyle bu çağda toplum, sosyal medya platformlarını sıklıkla kullanmaktadır. Dolayısıyla acentaların sosyal medya pazarlamasına yönelmelerinin önem taşıdığı ve katkı sağlayacağı yönündeki öneri, çalışmanın önemli çıktıları arasinda yer almaktadir.

Araştırma sonucunda seyahat acentalarının sosyal medya pazarlaması ile ilgili herhangi bir eğitim almadıkları sonucuna ulaşılmıştır. Hâlbuki işletme çalışanlarının sosyal medya pazarlaması konusunda eğitim almaları halinde önemli avantajlar sağlayacağı bilinmektedir. Eğitimli "Sosyal Medya Pazarlamacı"ları sayesinde; ürünler daha geniş kitlelere ulaştırılacak, ne tür içeriklerin tüketicilerin dikkatini çekeceği bilinecek, tüketici ile etkili iletişim konusunda bilinçli olunacaktır. Haliyle işletmenin sosyal medya üzerinden pazarladığı ürünlerin satışı ve buna bağlı olarak gelirleri de olumlu yönde gelişim gösterecektir. 
Yapılan içerik analizi sonuçlarına göre; acentaların sahip olduğu farklı sosyal medya bağlantılarının, onlar tarafından kullanılan "Instagram" hesaplarında ilan edilmediği/yer verilmediği tespit edilmiştir. Bu bulgulara dayanarak işletmelerce kullanılan diğer sosyal medya hesapları ile "Instagram" hesaplarının bağlantılı şekilde kullanılmadığı sonucuna ulaşılmıştır. Bilindiği üzere işletmenin farklı sosyal medya platformların da yer alması ve tüm platformları bağlantılı şekilde kullanması farklı potansiyellere sahip tüketicilere ulaşmada kolaylık sağlamaktadır. Bu nedenle Rize ili seyahat acentalarının farklı sosyal medya platformlarında yer alması ve tüm platformları bağlantılı şekilde kullanması önerilebilir. Çünkü bu durum farklı potansiyele sahip tüketicilere ulaşmada kolaylık sağlayacaktır.

Rize ili seyahat acentalarının ürün paylaşımı yanında tüketicilerinde içerisinde bulunduğu paylaşımlara önem verdiği görülmektedir. Bu durum diğer tüketicilerin acentayı tercih etmesini ve acentaya karşı güvenin artmasını sağlayan önemli faktörlerden biridir. Diğer taraftan acentalar, sosyal medya hesaplarından çoğunlukla fotoğraf paylaşımı yapmaktadırlar. Halbuki tüketicinin istek ve ihtiyaçlarına uygun hazırlanmış video içerikleri, tüketici ile işletme arasındaki etkileşimi daha fazla arttırmaktadır. Bu noktada acentaların video içerikli paylaşımları daha fazla kullanmaları önerilebilir.

Acentalar "Instagram" hesaplarında marka logolarını kullanırken; yapmış oldukları gönderilerde marka logosu ve slogana yer vermemektedirler. Acentaların yapmış oldukları paylaşımlarda da, marka logosu ve slogana yer vermeleri tüketici zihninde oluşacak marka imajına ve markaya karşı tutumlarına olumlu katkı sağlayacaktır. İnceleme yapılan acentaların hepsi gönderilerinde "hashtag" kullanımına önem vermektedirler. "Hashtag” kullanımı ürünlerin ve işletmenin tanıtımında daha geniş kitlelere ulaşması için yardımcı olmaktadır. Bu durumda işletmelerin ürün tanıtımında kullandıkları "hashtag" ile işletmeyi takip etmeyen kişilere de kolaylıkla ulaşım sağlamaları mümkün olacaktır. Böylelikle "hashtag” kullanımı ile marka farkındalığı arttırılacaktır.

Acentaların "Instagram" hesaplarında ürünleri ile ilgili herhangi bir promosyon duyurusunu paylaşmadıkları sonucuna ulaşılmıştır. Ürün promosyonları, farklı hedef kitlelere ulaşıp acentalara yeni müşteriler kazandırılmasında ve satışların özendirilmesinde önemli katkılar sunmaktadır. Dolayısıyla Rize ili seyahat acentalarının sosyal medya paylaşımları arasına promosyon duyurularını dâhil etmeleri, sosyal medya pazarlamasının etkinliğine katkı sağlayacağı söylenebilir.

Acentalar, paylaşımlara yapılmış olan yorumlara cevap vererek tüketici ile acentaları arasında etkileşimin artmasına katkı sağlarlar. Acentalar; tüketiciler tarafından yapılan yorumlar arasında "farklı kişilerin etiketlenmesi" ve "emojilerin" yoğunlukla kullanıldığını ifade etmiştir. 
Farklı kişilerin yorumlara etiketlenmesi, ürünlerin farklı hedef kitlelere de ulaşmasında çok etkili bir yöntem olup, tüketiciler de acentanın ürünlerinin tanıtımına katkı sağlamaktadır. İçerik analizi yapılırken tespit edilen "emojilere" dikkat edildiğinde, tüketiciler tarafından "gülücük" ve "kalp" emojilerinin daha fazla kullanıldığı tespit edilmiştir. Buradan yola çıkarak tüketiciler ürün ya da hizmetle ilgili memnuniyetlerini ve beğenilerini yazı ile değil de "emoji" ile dile getirdikleri sonucuna varılmıştır. Acentanın paylaşımları altına yapılan yorumlara cevap vermesiyse, diğer tüketicilerinde ürün ya da hizmet hakkında daha detaylı bilgi edinmesine katkı sağlamaktadır. Buna bağlı olarak ürün ya da hizmetleri tecrübe etmemiş tüketiciler için satın alma kararı kolaylaşacaktır. Buna ek olarak yorum yapan tüketicinin "sorununa" ya da "sorusuna" cevap verilmesi, tüketicinin düşüncesi yahut sorunlarıyla ilgilenildiği algısıyla, tüketicinin kendini değerli hissetmesine katk1 sağlayacaktır. Böylelikle tüketici ile işletme arasında etkileşim ve iletişim olumlu şekilde sonuçlanacaktır. Ayrıca müşteri sadakati olumlu yönde etkilenecektir.

Acentalar her ne kadar sosyal medya pazarlamasını kullanıyor olsalar da, önemli olan bu durumun etkin ve sürdürülebilir şekilde devam ettirilmesidir. Bundan dolayı acentaların sosyal medya pazarlaması ile ilgili profesyonel eğitimler alarak sosyal medya platformlarını etkin ve verimli şekilde kullanmaları, işletme açısından daha etkin sonuç alınmasına yardımcı olacaktır. Acentaların müş̧erilerle yakından etkileşim kurması ve sürekli olarak sosyal medya hesaplarını güncel tutması amacıyla, işletme bünyesinde sosyal medya pazarlaması için ayrı bir personel bulundurulması olumlu sonuçlar doğuracaktır. Acentaların sosyal medya platformlarında paylaştıkları gönderileri sadece Türkçe dilini kullanarak değil, farklı pazarlara da ulaşabilmek için, İngilizce veya hitap ettiği pazarın kullanmış olduğu dil seçeneği ile ürün tanıtımına da önem vermeleri bir diğer önemli husus olarak göze çarpmaktadır. Acentalar tasarladıkları promosyonları sosyal medya platformlarından tüketicilerine tanıtmaları, ürün ya da hizmet satışlarını arttıracaktır. Dolayısıyla Rize ili seyahat acentalarının çeşitli promosyonları tasarlamaları ve sosyal medya platformlarından tanıtmaları gerekmektedir. Sosyal medya platformlarının sürekli kendini yenilemesi, acentalar tarafından göz ardı edilmemeli ve bu yeniliğe ayak uydurarak rakip firmalara karşı rekabet avantajı elde edilmelidir.

Yazar Katkısı: Bu çalışmada yazarların çalışmaya katkısı tamdır. Her iki yazar çalışmanın bütününde iş birliği ve ortak çalışmayı esas almıştır. Çalışmada yer alan literatür özeti, alan araştırması ve verilerin analizi kısımları yazarların ortak çabasıyla tamamlanmıştır.

Çıkar Beyanı: Bu çalışmada yazarlar arasında herhangi bir çıkar çatışması bulunmamaktadir.

\section{Kaynakça}

Aspasia, V. ve Ourania, N. (2014). Social media adoption and managers' perceptions. International Journal on Strategic Innovative Marketing, 1(2), 61-63. 
Baş, M. (2015). Otel işletmelerinin sosyal medya kullanma nedenleri: İstanbul'daki beş yıldızlı otellerde bir araştırma. Yüksek Lisans Tezi, Düzce Üniversitesi, Sosyal Bilimler Enstitüsü, Turizm ve Otel İşletmeciliği Ana Bilim Dalı, Düzce.

Buhalis, D. ve Licata, M. C. (2002). The future e-Tourism intermediaries. Tourism management, 23(3), 207-220.

Burgess, S., Sellitto, C., Cox, C. ve Buultjens, J. (2011). Trust perceptions of online travel information by different content creators: Some social and legal implications. Information systems frontiers, 13(2), 221-235.

Buzlukçu, C. (2015). Butik ve küçük otel işletmeleri yöneticilerinin sosyal medya pazarlamasına ilişkin algılamalar. Yüksek Lisans Tezi, Muğla Sttkı Koçman Üniversitesi Sosyal Bilimler Enstitüsü, Turizm İşletmeciliği Ana Bilim Dalı, Muğla.

Can, L., ve Serhateri, A. (2016). Sosyal medya reklamlarının markaya yönelik tutuma etkisi: facebook üzerinde bir uygulama. Balkan ve Yakın Doğu Sosyal Bilimler Dergisi, 2(3), 16-28.

Castronovo, C. ve Huang, L. (2012). Social media in an alternative marketing communication model. Journal of Marketing Development and Competitiveness, 6(1), 117-134.

Civelek, M. ve Dalgın, T. (2013). Turizm pazarlamasında sosyal medya, turizm işletmeleri üzerine bir araştırma: Muğla örneği. 14. Ulusal Turizm Kongresi Bildiriler Kitabl, 266282, Kayseri.

Çelen, O. ve Tuna, M. (2018). Türkiye'deki gurmelerin ınstagram hesaplarının içerik analizi yöntemiyle incelenmesi. Journal of Tourism and Gastronomy Studies, 6(3), 411-436.

Çetin, F. A., ve Taşdemir, N. H. (2018). Sürdürülebilir sosyal medya pazarlaması ve markaların sosyal medyada sürdürülebilirliğe karş1 tutumu. Journal of Institute of Economic Development and Social Researches, 4(8), 31.

Çiftçi, Ö. G. H. (2016). Turistik destinasyon ürünlerinin popülerleşmesinde sosyal medyanın rolü. Akademik Sosyal Araştırmalar Dergisi, 4(33), 544-551.

Demirci Orel, F. ve Arık, A. (2019). Sosyal medya pazarlamasının tüketici satın alma niyetine etkisinin teknoloji kabul modeli aracılı̆̆yla incelenmesi. Erciyes Üniversitesi Iktisadi ve İdari Bilimler Fakültesi Dergisi, (57), 239-266.

Erdoğmuş, İ. E., ve Cicek, M. (2012). The impact of social media marketing on brand loyalty. Procedia-Social and Behavioral Sciences (58), 1353-1360.

Eröz, S. S.ve Doğdubay, M. (2012). Turistik ürün tercihinde sosyal medyanın rolü ve etik ilişkisi. Dokuz Eylül Üniversitesi İktisadi İdari Bilimler Fakültesi Dergisi, 27(1), 133157.

Eryılmaz, B. ve Şengül, S. (2016). Sosyal medyada paylaşılan yöresel yemek fotoğraflarının turistlerin seyahat tercihleri üzerindeki etkisi. Uluslararası Türk Dünyası Turizm Araştırmaları Dergisi, 1(1), 32-42.

Gulbahar, M. O., ve Yildirim, F. (2015). Marketing efforts related to social media channels and mobile application usage in tourism: Case study in Istanbul. Procedia-Social and Behavioral Sciences, 195(3), 453-462.

Gümüş, N. ve Kütahyali, D. N. (2017). Kobi'lerin pazarlama çalışmalarında sosyal medya kullanma ve kullanmama nedenlerinin belirlenmesi: Kastamonu ilinde bir araştırma. Uluslararası Yönetim İktisat ve Işsletme Dergisi, 13(4), 891-910. 
Hartline, J., Mirrokni, V. ve Sundararajan, M. (2008). Optimal marketing strategies over social networks. In Proceedings of the 17th international conference on World Wide Web, 189-198, Beiji.

Hays, S., Page, S. J. ve Buhalis, D. (2013). Social media as a destination marketing tool: its use by national tourism organisations. Current issues in Tourism, 16(3), 211-239.

Huang, Y., Basu, C. ve Hsu, M. K. (2010). Exploring motivations of travel knowledge sharing on social network sites: an empirical investigation of US college students. Journal Of Hospitality Marketing ve Management, 19(7), 717-734.

Inversini, A., Cantoni, L. ve Buhalis, D. (2009). Destinations' information competition and web reputation. Information Technology and Tourism, 11(3), 221-234.

İslek, M. S. (2012). Sosyal medyanın tüketici davranışlarına etkileri: Türkiye'deki sosyal medya kullanıcllarl üzerine bir araştırma, Yüksek Lisans Tezi, Karamanoğlu Mehmet Bey Üniversitesi, Sosyal Bilimler Enstitüsü, İşletme Ana Bilim Dalı, Karaman.

Jones, N., Borgman, R. ve Ulusoy, E. (2015). Impact of social media on small businesses. Journal of Small Business and Enterprise Development, 22(4), 611-632.

Karabulut, M. Ş. ve Bulut, E. (2017). Küçük ve orta büyüklükteki işletmelerin sosyal medya pazarlamasına bakış1: Sinop ilinde bir araştırma. Karabük Üniversitesi Sosyal Bilimler Enstitüsü, 7(1), 70-88.

Karamehmet, B., ve Aydın, G., (2017). Turizm sektöründe sosyal medya kullanım etkinliğinin iyileştirilmesi: 5 yıldızlı oteller üzerinde bir çalışma. Uluslararası Ikktisadi ve İdari Incelemeler Dergisi, 593-606.

Kaşl1, M. (2006). Konaklama işletmelerinde bilgi teknolojilerinin pazarlama aracı olarak kullanımı: Balıkesir'de bir araştırma. Yüksek Lisans Tezi, Balıkesir Üniversitesi, Sosyal Bilimler Enstitüsü, Turizm İşletmeciliği ve Otelcilik Anabilim Dalı, Balıkesir.

Kılıç, B., Kırlı, G. ve Esen, F. Ö. (2017). Sosyal Medya kullanımı benlik algısı ilişkisi: turistik tüketiciler üzerine bir araştırma. Gaziantep University Journal of Social Sciences, 16(1), 70-85.

Leblebeci Koçer, L., ve Arslan Koçkaya, F. (2016). Tüketicilerin sosyal medya reklamlarına yönelik tutum ve düşüncelerinin satın alma davranışlarına etkisi. Journal of International Social Research, 7(43), 2052-5062.

Leung, D., Law, R. ve Lee, H. A. (2011). The perceived destination image of Hong Kong on Ctrip. com. International Journal of Tourism Research, 13(2), 124-140.

Özeltürkay, E. Y., Bozyiğit, S. ve Gülmez, M. (2017). Instagram'dan alışveriş yapan tüketicilerin satın alma davranışları: Keşifsel bir çalışma. Öneri Dergisi, 12(48), 175198.

Özturan, M. ve Roney, S. A. (2004). Internet use among travel agencies in Turkey: an exploratory study. Tourism Management, 25(2), 259-266.

Pan, B., MacLaurin, T. ve Crotts, J. C. (2007). Travel blogs and the implications for destination marketing. Journal of Travel Research, 46(1), 35-45.

Park, J. ve Oh, I. K. (2012). A case study of social media marketing by travel agency: The salience of social media marketing in the tourism industry. International Journal of Tourism Sciences, 12(1), 93-106.

Rize İl Kültür ve Turizm Müdürlüğ̈̈ (2020). Tesisler ve acentalar. (10.03.2020) https://rize.ktb.gov.tr/TR-272448/seyahat-acentalari.html. 
Russell, J. (2010). Evaluate the effectiveness of social media marketing on hotels. Hospitality Management Review Student Journal at Sheffield Hallam University, (1), 1-22.

Seo, E. J. ve Park, J.W. (2018). A study on the effects of social media marketing activities on brand equity and customer response in the airline industry. Journal of Air Transport Management, (66), 36-41.

Şahin, E., Çağlıyan, V. ve Başer, H. H. (2017). Sosyal Medya Pazarlamasının Tüketici Satın Alma Davranışına Etkisi: Selçuk Üniversitesi İI BF Örneği. Ömer Halisdemir Üniversitesi Iktisadi ve İdari Bilimler Fakültesi Dergisi, 10(4), 67-86.

Tekeli, A. (2018). Konaklama işletmelerinde sosyal medya kullanılması ve yöneticilerin sosyal medya pazarlamasına yönelik algılamaları: Fethiye ilçesinde bir uygulama. Yüksek Lisans Tezi, Dumlupınar Üniversitesi, Sosyal Bilimler Enstitüsü, İşletme Anabilim Dalı, Kütahya.

Torun, E. (2017). Tüketici satın alma davranışları üzerinde internet ve sosyal medyanın yeri ve önemi. Elektronik Sosyal Bilimler Dergisi, 16(62), 955-970.

Vrana, V. ve Zafiropoulos, C. (2006). Tourism agents' attitudes on internet adoption: an analysis from Greece. International Journal of Contemporary Hospitality Management, 18(7), 601-608

Weinberg, T. (2009). The new community rules: Marketing on the social web. New York: O'Reilly: California.

Xiang, Z. ve Gretzel, U. (2010). Role of social media in online travel information search. Tourism Management, 31(2), 179-188.

Yanar, K., ve Yılmaz, K. G. (2017). Sosyal medyanın satın alma öncesi ve sonrası tüketici davranışına etkisi üzerine bir araştırma. Yönetim, Ekonomi ve Pazarlama Araştırmaları Dergisi, 1(2), 24-40.

Yeniçıktı, N. A., (2016). Halkla ilişkiler aracı olarak Instagram: sosyal medya kullanan 50 şirket üzerine bir araştırma, Selçuk Üniversitesi İletişim Fakültesi Akademik Dergisi, 9(2), 92115 .

Yıldırım, G. ve Erkılıç, E. (2019). Rize'deki konaklama işletmelerinin sosyal medya kullanımı üzerine bir araştırma. Journal of Tourism Theory and Research, 5(3), 380-395.

Yıldız Sanay, G. (2017). Elektronik turizm pazarlamasında güncel yaklaşımlar ve sosyal medyanın turistlerin destinasyon seçimi üzerindeki etkileri ve analizi. Yüksek Lisans Tezi, Haliç Üniversitesi, Sosyal Bilimler Enstitüsü, İşletme Anabilim Dalı, İstanbul.

Yılmazdoğan, C. O. (2013). Otellerde sosyal medya pazarlamasının yararlarına yönelik yönetici algılarının belirlenmesi: Antalya örneği. Yüksek Lisans Tezi, Anadolu Üniversitesi Sosyal Bilimler Enstitüsü, Turizm İşletmeciliği Anabilim Dalı, Eskişehir.

Yılmazdoğan, C. O. ve Özel, H. Ç. (2014). Sosyal medya pazarlamasının otellerdeki kullanımının yararların yönelik yönetici algılarının belirlenmesi: Antalya örneği. İsletme Fakültesi Dergisi, 15(1), 37-62.

Yung, C. Y. (1997). Internet marketing: the perception of travel agencies in Taipei, Taiwan. Asia Pacific Journal of Tourism Research, 2(1), 67-74. 